\title{
Smart technologies driven approaches to tackle COVID-19 pandemic: a review
}

\author{
Hameed Khan ${ }^{1} \cdot$ K. K. Kushwah ${ }^{2} \cdot$ Saurabh Singh ${ }^{3} \cdot$ Harshika Urkude $^{3} \cdot$ Muni Raj Maurya $^{4,5}$. \\ Kishor Kumar Sadasivuni ${ }^{5}$
}

Received: 30 July 2020 / Accepted: 1 December 2020 / Published online: 11 January 2021

(c) King Abdulaziz City for Science and Technology 2021

\begin{abstract}
The novel coronavirus infection (COVID-19) is not diminishing without vaccine, but it impinges on human safety and economy can be minimized by adopting smart technology to combat pandemic situation. The implementation of new innovations and novel tactics has proven to be effective in curbing the risk of COVID-19. The present study covers the role of smart technology in mitigating the spread of COVID-19 with specific focus on advancement in the field of drone, robotics, artificial intelligence (AI), mask, and sensor technology. The findings shed light on the robotics and drone technology-driven approaches that have been applied for assisting health system, surveillance, and disinfection process, etc. The AI technology strategies and framework is highlighted in terms of bulk data computing, predicting infection threats, providing medical assistance, and analyzing diagnosis results. Besides this, the technological shift in mask and sensor technology during the pandemic have been illustrated, which includes fabrication method like 3D printing and optical sensing, respectively. Furthermore, the strength, weakness, opportunities, and possible threats that have been shaped by the rigorous implementation of these technologies are also covered in detail.
\end{abstract}

Keywords COVID-19 $\cdot$ Robot $\cdot$ Drone $\cdot$ Artificial intelligence $\cdot$ Mobile apps $\cdot$ Sensor

\section{Introduction}

Coronavirus 2019 (COVID-19) is a human infectious disease linked with severe respiratory distress. Seeing the impact of COVID-19 infection on human health and its outbreak, since 30 January 2020, World Health Organiza-

K. K. Kushwah

kamal_kushwah2005@yahoo.com

Saurabh Singh

ssingh@jecjabalpur.ac.in

$\triangle$ Kishor Kumar Sadasivuni

kishor_kumars@yahoo.com

1 Department of Computer Science, GRKIST, Jabalpur, Madhya Pradesh, India

2 Department of Applied Physics, Jabalpur Engineering College, Jabalpur, Madhya Pradesh 482001, India

3 Department of Computer Science and Engineering, Jabalpur Engineering College, Jabalpur, Madhya Pradesh 482001, India

4 Mechanical and Industrial Engineering, Qatar University, Doha, Qatar

5 Center for Advanced Materials, Qatar University, Doha, Qatar tion (WHO) recognized it as Public Health Emergency of International Concern (PHEIC) (WHO 2020). Considering the rapid transmission of infection among masses, COVID19 has been given a status of pandemic disease (Lai et al. 2020). According to WHO, the best solution to curtail its widespread is by adopting precautionary measures at the early stage. To tackle the pandemic, the main focus of healthcare systems is to implement large-scale testing and effectively treating the infected individuals. Furthermore, to mitigate the infection and bring the sustainability in current pandemic situation, the other best solution at which governments are unanimously focusing is imposing lockdown in infection concerned regions. Thus, to simultaneously meet the requirement of the health system and implement the lockdown, a certain framework for shaping the society is required. Under these circumstances, smart technologies 
have made their impact in various sectors like healthcare, government, public and industries, etc. (Elavarasan and Pugazhendhi 2020). The sudden shift toward the techno-driven approaches has accelerated the demand for innovations and alternative strategies, and has pushed the limits of the technologies in almost every field (Javaid et al. 2020; Kumar et al. 2020; Singh et al. 2020). To handle the burden of frontline health system warriors, technologies like telehealth (STAT 2020), artificial intelligence (AI) (Alsuliman et al. 2020; Nguyen 2020), robotics (European Parliament 2020), and drone (dJI enterprise 2020), etc. have gone up multiple folds during the pandemic. Drone and robot technology has been configured to assist in the disinfection process, delivery of medical supply, surveillance, and screening of individuals for early detection of infection, etc. Moreover, the robotics has been widely applied in providing medical consultation to patients and healthcare workers. The rapid increase in the COVID-19 cases and it impinges on human safety has created a necessity to analyze bulk data for making protocols to tackle the pandemic situation. Under the context, the AI and data-driven applications have encouraged the development of strategic framework to enhance the detection, tracking, and data analysis, which has a direct influence on mitigating the spread of infection (OECD.AI 2020). With ability to work autonomously, self-learn to improve with addition of new data set and draw imperatives in short span of time, AI has been implemented in predicting regions with infection threats, medication, and computing diagnosis results, etc. Even mobile phone network is trusted as one of the key avenues in tackling the pandemic situation. In recent time, mobile phone technology is spread all across the cities and virtually connects person to larger masses. Seeing mobile phone network as the veins of cities smartphone applications (Apps) has been utilized as perfect template to communicate with larger masses. Various mobile Apps were developed to spread awareness among people, provide medical assistance, and most important to curb the spread of COVID-19 through contact tracing. As we prepare to step out and bring normalcy in the daily life, authorities are focusing on the implementation of protective measures and rapid testing methods. In this regard, the use of face mask has proven to be effective in limiting the spread of the COVID-19. As a result, a sudden surge in the demand of mask has led to novel innovations in the mask fabrication technology. On the other hand, worldwide researchers are engaged in developing point-of-care products that will assist in rapid testing of COVID-19 (Udugama et al. 2020). The combined effort from various sectors, implementation of technologies, and effective governance together has created a defense line to fight against COVID-19. Seeing the astonishing contribution of the technologies in combating COVID-19 infection, it becomes essential to understand how these innovations are synergistically helping to overcome the pandemic situation.
The present review highlights the hidden roles of smart technologies and reveals its potential in controlling the pandemic situation (see Fig. 1). The study includes a detailed investigation of viable technologies based strategies that are influencing in controlling the pandemic along with the changes that these technologies have undergone to exploit their potentials to the fullest. The article helps scholars, professionals, and readers to recognize how the implementation of technologies is synergistically assisting in controlling the spread of the coronavirus infection and, also, persuade the implementation of these technologies in current or future emergency situations.

\section{Drone technology}

The use of technology such as drones (autonomous machines) has a crucial role in responding to the COVID19 pandemic. Drones assist authorities and people in different ways to prevent the spread of coronavirus infection and stop unwanted movements of peoples during the lockdown. Authorities are using drones for purposes like medical supply, surveillance, disinfection, screening infection symptoms, and public awareness etc., as shown in Fig. 2. Drones technology is feasible to carry all these tasks and even enables its service in interior regions without any person-toperson contact.

\section{Delivery}

In the coronavirus pandemic situation, drones have been extensively adopted for faster and safe transfer of essential products. The delivery approach can be classified in two perspectives, first is supply of food items/basic needs and second is delivering health care facilities, which include test samples to labs, medicines and personal protective equipment (PPE) kit, etc. (Poljak and Šterbenc 2020). To reduce the load on the healthcare system, drones are applied for collecting test samples from localized/remote areas and transport them to the nearest testing lab. This approach makes the transportation faster and even minimizes the risk of virus spread. A more-advanced and potential concept called 'lab-on-a-drone' is suitable where the delivery of diagnosis equipments is difficult and for laboratories that are located in a remote area. The 'lab-on-a-drone' technology couples drone with sample preparation and diagnostic platforms, which intern reduces the testing time (Priye et al. 2016). A startup company in California named 'Zipline' has been actively using drone technology for the past few years to deliver medical supplies in regions like Ghana and Rwanda (Bloomberg 2020). During the COVID-19 outbreak, under national pilot programs, the Chinese government accelerated the use of drones to deliver tons of medical supplies 


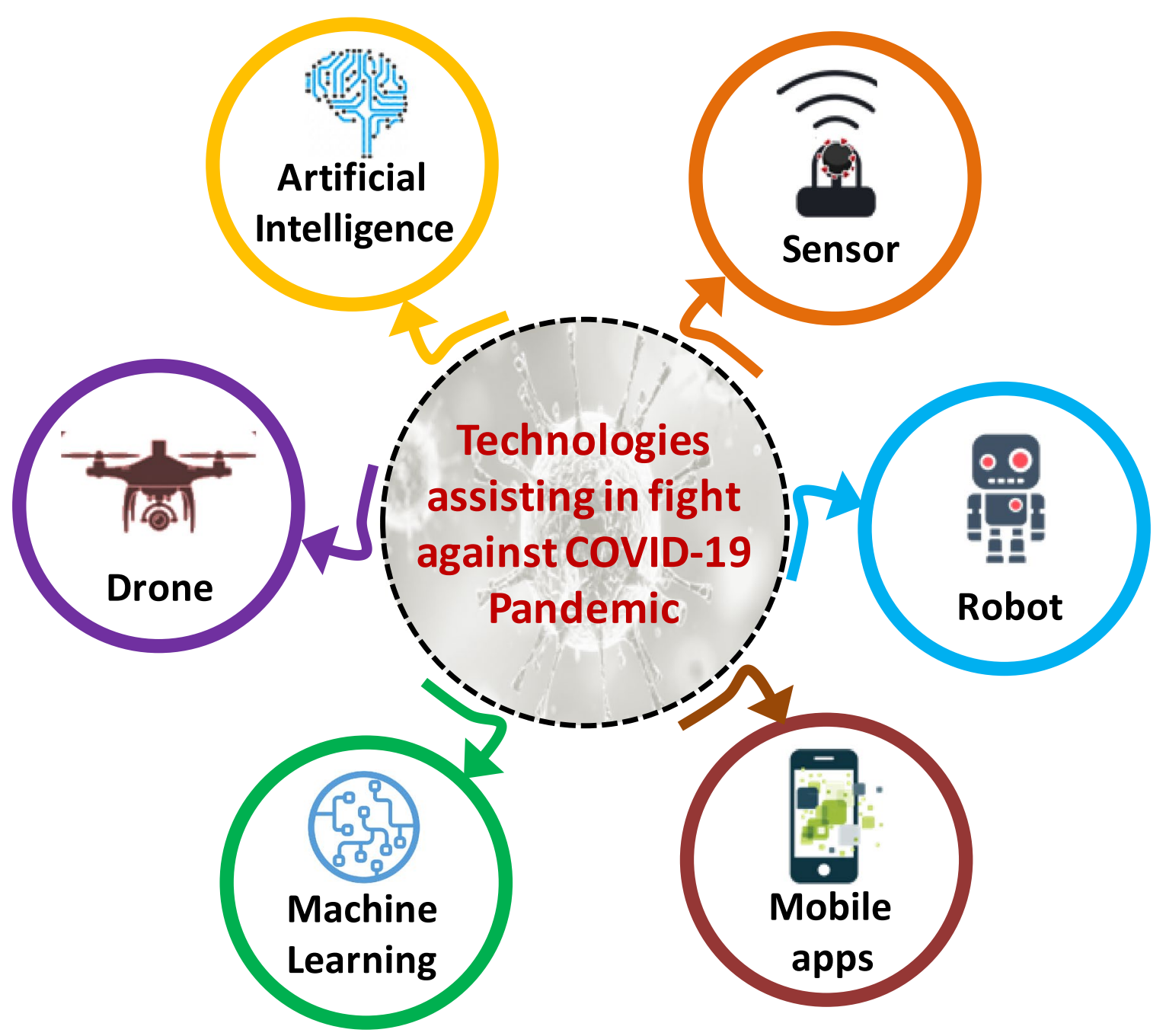

Fig. 1 Schematic showing various smart technologies assisting in mitigating COVID-19 pandemic

and parcels in virus-infected areas (Twitter 2020a). Drones helped in quick diagnosis by delivering test samples to laboratories (BBC 2020a) and are much safe to transport medical supplies into hospitals treating COVID-19 patients (Nikkei Asian Review 2020). Moreover, drone-based delivery approach took humans out of the process which helps in curtailing the spread of coronavirus and also reduces delivery time. The various drone technology-assisted delivery strategies adopted by different countries are listed in Table 1 .

\section{Surveillance and broadcast}

Most countries took measures like closing non-essential public places, ban mass gatherings, and social distancing policy to limit physical contact. The major issue is how governments, organizations, and societies should perform surveillance with minimum effort and without any physical contact. In this regard, authorities are using drones to monitor people's movement and avoid social gatherings that could pose a risk to society (Vacca and Onishi 2017). Drones are being used in broadcasting messages and imparting awareness among the public through loudspeakers and even digital displays are widely used in many countries (Mishra et al. 2020). Using a global positioning system (GPS) enabled drone management system; authorities can easily detect unwanted activity even in the crowded areas.

\section{Disinfection}

Till now, no medicine or vaccine has been developed for curing COVID-19 infection, and as a result, authorities are much focused on prevention methods. Controlling coronavirus infection by prevention methods is a gradual process and may take months, and thus, to bring stability in the economy, governments are giving relaxation in lockdown. As we prepare to step out and bring normalcy in daily life, it becomes

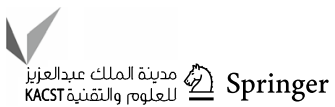




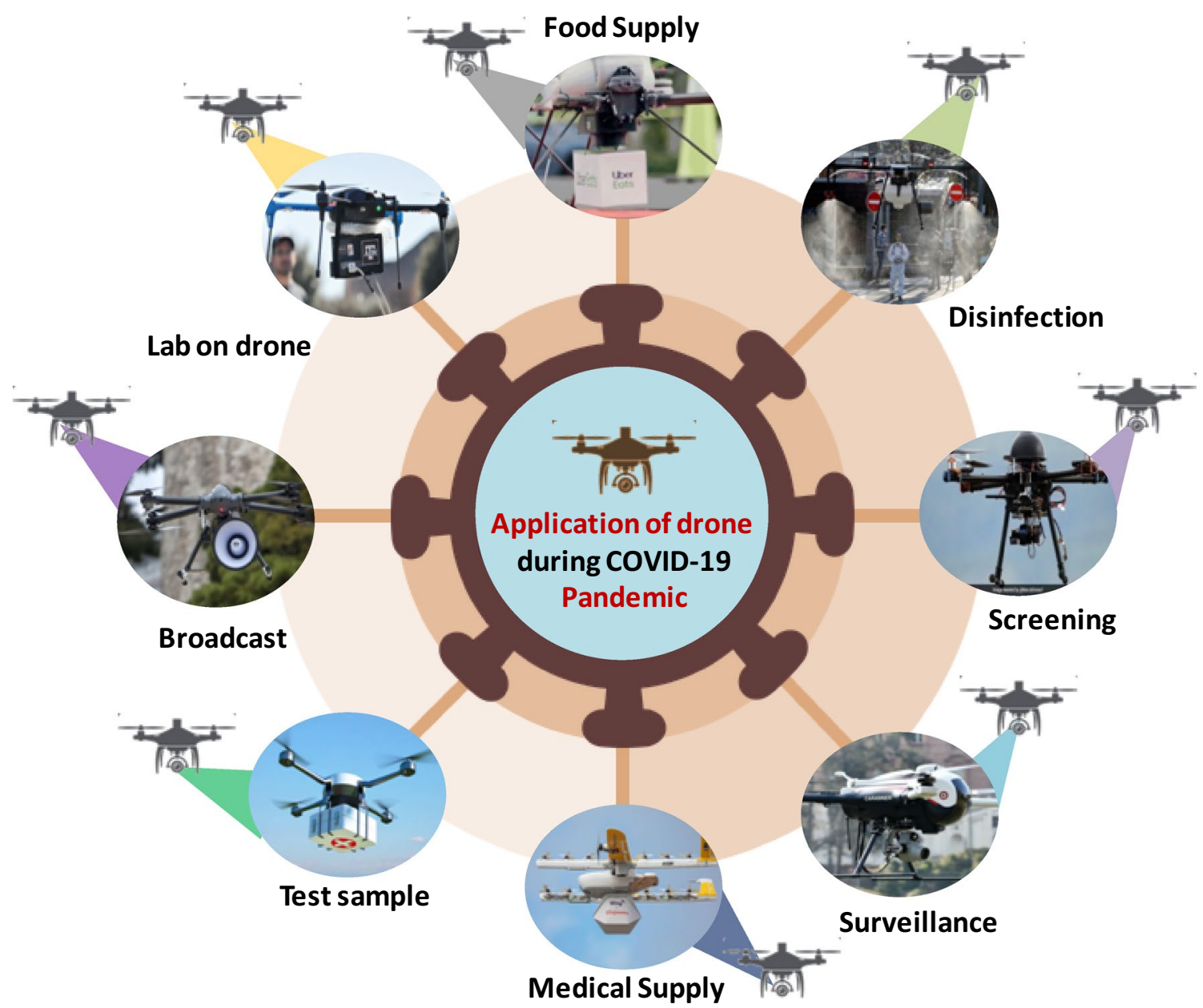

Fig. 2 Schematic showing the implementation of drone technology in various fields to combat COVID-19 pandemic

even more important to frequently disinfect places of highrisk like parks, public transport, and open market, etc. To implement it, authorities have come up with a solution of deploying agriculture spraying drones for frequent disinfection of high-risk area within short span of time (China Daily 2020; Clay and Milk 2020). The area covered and the speed by which these drones can disinfect are unparallel compared to other spray techniques.

\section{Screening}

One of the common ways of coronavirus transmission is a person-to-person interaction. Thus, it is important to identify the infected person and the possible infected person due to contact at an early stage. The idea is to perform bulk and rapid screening around the regions with minimum human-to-human interaction. Under the context, drone technology has emerged as a game changer and assisted in symptom-based bulk screening of individuals.
These drones are installed with the temperature sensor to screen the people from their homes. They are also equipped with the camera to take pictures of the person and GPS to track the location. To enhance the screening accuracy, technology that remotely monitors the respiratory conditions is coupled with drones and is referred to as "Pandemic Drone" (HIT consultant 2020a; Forbes 2020). Originally, the pandemic drones were developed for remote monitoring in natural disasters and war zones. The unique technology incorporated computer vision system and specialized sensor to monitor respiratory rates, heart rates, temperature, as well as coughing in crowds. To combat the global spread of coronavirus in the United States of America, authorities have deployed a pandemic drone named 'Draganfly' that remotely monitors and detects people with infectious and respiratory conditions (GPS World 2020b). The technology offers health assessment at a large area within short duration of time and a large number of persons can be monitored frequently and on a daily basis. 
Table 1 List of various countries using drone technology for delivering medical supply and other essential products

\begin{tabular}{|c|c|c|c|}
\hline Country & Function & Information & References \\
\hline Australia & Medical supply & $\begin{array}{l}\text { Skyrocket, a Google project initiates cargo drone } \\
\text { deliveries }\end{array}$ & Twitter (2020b) \\
\hline Canada & Medical supply & $\begin{array}{l}\text { Drone Delivery Canada (DDC) Sparrow, a multi-task } \\
\text { drone transports hygiene kits, PPE, COVID-19 test } \\
\text { swabs and can carry about } 10 \mathrm{lb} \text { of payload }\end{array}$ & Inside unmanned systems (2020) \\
\hline Chile & Medical supply & $\begin{array}{l}\text { High-tech drones transport sanitizer, masks, and medi- } \\
\text { cations across the rural South American nation and in } \\
\text { remote areas }\end{array}$ & Reuters (2020) \\
\hline China & Medical and commercial products & $\begin{array}{l}\text { JD Logistics drones deliver commercial cargo and } \\
\text { medical supplies }\end{array}$ & Supply Chaindive (2020) \\
\hline China & Medical supply and Test sample & $\begin{array}{l}\text { Antwork uses cargo drones to deliver supplies to quar- } \\
\text { antine people and also medical samples for test }\end{array}$ & GPS World (2020a) \\
\hline Estonia & Test sample & $\begin{array}{l}\text { Threod Systems and The North Estonia Medical Center } \\
\text { use drones to transport COVID-19 samples to labs }\end{array}$ & ERR.ee (2020) \\
\hline Germany & Test sample & $\begin{array}{l}\text { Becker and Kollegen and Quantum Systems use a } \\
\text { drone to transport COVID-19 samples to the Munich } \\
\text { laboratory }\end{array}$ & Quantum systems (2020) \\
\hline Ghana & Medical supply and Test sample & $\begin{array}{l}\text { Zipline drones transport around } 200 \text { medical products } \\
\text { that include health facilities, PPE, plasma, blood and } \\
\text { vaccines, etc }\end{array}$ & The World (2020) \\
\hline Ireland & Medical and other supply & $\begin{array}{l}\text { Health Service Executive is working with Manna Aero } \\
\text { to transport essential supplies and medicines }\end{array}$ & $\mathrm{BBC}(2020 b)$ \\
\hline Italy & Medical supply & $\begin{array}{l}\text { Industrial drones deliver medicines and COVID-19 test } \\
\text { swabs }\end{array}$ & UAS magazine (2020) \\
\hline Poland & Test sample & $\begin{array}{l}\text { Warsaw, Central Clinic Hospital uses Hermes V8Mt } \\
\text { drones to transport patient samples for testing }\end{array}$ & La Opinion (2020) \\
\hline Scotland & Medical supply & Wingcopter drones deliver PPE and test kits & The guardian (2020) \\
\hline Singapore & Medical supply & Drones deliver medicines to cargo ships & We Robotics (2020) \\
\hline South Korea & Medical supply & $\begin{array}{l}\text { In response to the coronavirus pandemic, hydrogen } \\
\text { powered drone transports protective masks }\end{array}$ & H2 view (2020) \\
\hline Turkey & Food supply & $\begin{array}{l}\text { In a lockdown, a bakery owner uses a drone to deliver } \\
\text { food items to the customers }\end{array}$ & Twitter (2020c) \\
\hline United Kingdom & Medical supply & $\begin{array}{l}\text { National Health Service (NHS) delivers medical sup- } \\
\text { plies using drones }\end{array}$ & $\mathrm{BBC}(2020 \mathrm{c})$ \\
\hline $\begin{array}{l}\text { United States } \\
\text { of America } \\
\text { (USA) }\end{array}$ & Medical supply & $\begin{array}{l}\text { Zipline and Matternet use drones to supply medical } \\
\text { deliveries in North Carolina }\end{array}$ & Fierce Electronics (2020) \\
\hline
\end{tabular}

\section{Robot technology}

Robotics has proven its caliber in many fields and can assist in many ways. The technology has proven its potential in many aspects like delivery of medicine, surveillance, screening of patients and disinfection, etc. The application of robots in healthcare systems has shown encouraging solutions for preventing the escalation of COVID-19. With the simultaneous incorporation of machine learning algorithms and $\mathrm{AI}$, robots have turned out to be more effective in the treatment and diagnosis of infection. For instance, robots are used for bulk screening and acquire data to interpret the health report of individuals. In pandemic situations like coronavirus, autonomous robot system has provided substantial support to health workers by performing repetitive tasks with a low margin of error. Robot technology can be classified based on the effective level of communication between robots and humans. Figure 3 shows the classification of robot technology along with examples depicting its application in the COVID-19 pandemic. A detailed discussion of the various robot technologies listed in Fig. 3 is carried out in the next section.

\section{Tele-robot}

Tele-robot is the technology that can be used to handle robot from distance using a wireless communication network like Internet. During the COVID-19 pandemic, assisting the healthcare system with human-operated tele-robots has proven to be much safer and effective technology. The robots 


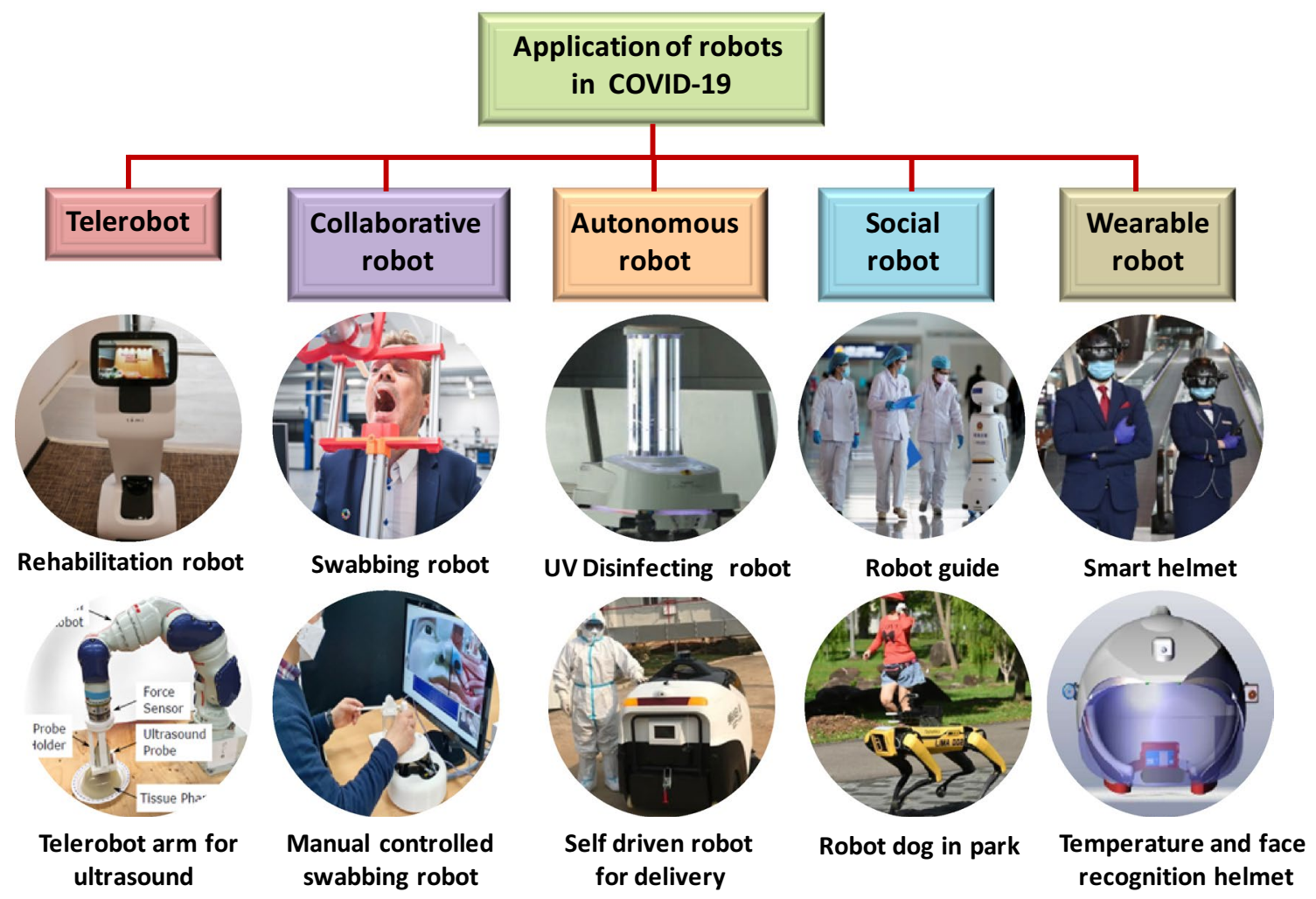

Fig. 3 Schematic representing the classification of the robot technology along with examples illustrating their application in the COVID-19 pandemic

can be easily sterilized from time to time, which makes their use effective during screening and intake of patients. The 'Intuitive' made 'daVinci Surgical Robot' has received much attention in this field and works with a surgical software console that can be operated by a physician (Intuitive 2020). Another example is using a teleoperated robot arm to perform ultrasound examinations (Carriere et al. 2019). Along with this, by clubbing tele-robots with mobile phone software, it is possible to use the instrument for a regular check-up of blood oxygen level, pulse, blood pressure, and temperature, etc. Apart from this, tele-robots are used in hospitals and in the community for secondary healthcare operations like screening, redirecting patients for isolation, and providing assistant during rehabilitation. Tele-robotics assisted tele-rehabilitation is employed to connect with patients at residence and guide them with their cognitive or physical rehabilitation activities (Agostini et al. 2015; Fong et al. 2019; Tao et al. 2020). Using this technology, people with a high risk of getting affected can remain at their home and can receive rehabilitation therapy through a distance.

\section{Collaborative robot}

Collaborative robots are intended to augment the humanoperated process and work in close proximity to physically interact with humans. Compared to tele-robots, the collaborative robots do not have the capability to work in isolation without human intervention, but have the ability to adapt with task changing dynamics. Collaborative robot can be incorporated for initial testing like collecting and testing oropharyngeal and nasopharyngeal swabs (Evening Standard 2020). This will reduce the risk, speed up the process, and allow bulk testing. Under this context, a team at the University of Southern Denmark has developed a robot that collects the swab from the throat interior and deposits it in the sample box (Healthcare Packaging 2020). Collaborative robots with augmented reality (AR) technology serve as trainers/ simulators for training healthcare workers and quickly assist them in various target activities. The robotic task simulators are used in the COVID-19 pandemic to train medical staff on highly dynamic procedures or technical protocols.

\section{Autonomous robot}

Autonomous robots are proficient enough to make decisions independently and accordingly take actions without any human intervention. During COVID-19, the most common and widely deployed autonomous mobile robot is UV sterilization robots. A wheeled UV disinfecting robot is used at places like hospitals, airports, shopping complexes and 
stores, etc. (Simple Flying 2020). Apart from this, wheeled autonomous robots are also used for visiting patient rooms and interact with them to record vital health information. On coupling these robots with manipulators, they can even perform some medical treatment (Tavakoli et al. 2020). A self-driving autonomous robot is used for supplying PPE, medication, equipment, and food supply, and can do other logistic work (Nikkei Asian review 2020b).

\section{Social robot}

Social robots have the ability to communicate and interact with persons and their surrounding environment. To make effective interaction with humans these robots are equipped with different types of actuators and sensors. Social robots are designed to resemble humanoids or toys with a head and can speak to interact with users. The motive of this kind of robots is to engage with persons in isolation, elderly persons, and persons with disabilities to provide them medical/mental assistance. These robots measure the infection symptoms, stress, and other vital signs via sensors embedded in them. In the COVID-19 pandemic, social robots are used for social interaction and guiding peoples in the hospital (The Peninsula 2020). Along with this, these robots are used at public places to help people follow the guidelines like social distancing and wearing face mask, etc. (Ecns.cn 2020).

\section{Wearable robot}

Wearable robot technology mainly refers to electronic devices that can be worn on the body and has the ability to perform an action and take decisions while assisting humans in computing, examining, and communicating the data. In the case of COVID-19, measured data can be a body activity corresponding to vital signs of symptoms. One such example is the use of thermal imaging helmets at places that confront a large number of visitors on daily basis (International Airport review 2020). Recently, Mohammed et al. proposed a smart helmet for temperature monitoring and even facialrecognition technology to display the pedestrian's personal information (Mohammed et al. 2020).

\section{Artificial intelligence}

Artificial Intelligence is considered as an emerging opportunity in the era of the Internet and virtual world. Many countries are leveraging AI to observe COVID-19 infections, inform healthcare systems, and set up rapid actions to curb its spread.

\section{Al-based data science modeling methods for COVID-19}

To monitoring and combat the pandemic, the world is exploring robust technology areas particularly in AI and statistical science. Recently, Australian Census-based Epidemic Model (ACEMod), previously used for influenza pandemic simulation (Zachreson et al. 2018; Cliff et al. 2018), was modified and calibrated for modeling the COVID-19 pandemic across Australia (Chang et al. 2020). Allam and Jones recommend the use of AI for managing health system and regulating protocols (Allam and Jones 2020). China adopted a deep learning-based autoencoder model to speculate real-time COVID-19 cases in the infected regions (Hu et al. 2020). Even, an AI-based model called as ' $\alpha$-Satellite' is projected to analyze the possible spread of the infection in an assigned area (Ye et al. 2020). The various immediate facts like death counts, public awareness through social media (Mirza and Osindero 2014), visitor's density, and demographic data are collected to assess the threat of infection in a region. Maghdid et al. proposed a framework to screen COVID-19 infection by clubbing built-in smartphone sensors with AI technology (Maghdid et al. 2020a, b). The intended AI-enabled protocol analyzes the smartphone sensor's data to estimate the infection severity in the user. In another work, deep learning method was employed for diagnosis by acquiring data and performs analysis corresponding to disease symptoms. For instance, videos and images obtained from smartphone camera or data screened through installed inertial sensors were studied for detecting human fatigue levels (Karvekar 2019; Roldán Jiménez et al. 2019). Likewise, condition of cough can be detected from the audio recorded through smartphone microphone (Nemati et al. 2019; Vhaduri et al. 2019). Even, the video obtained through smartphone can assist in the prediction of nausea (Story et al. 2019). Recently, a joint venture between India and Japan aims to hasten human health sector with novel innovation in smart technology system (Salzburg Global Seminar 2020). The association will focus on the development of autonomous system, robotics, AI, and blockchain technologies to deal with the challenge of health systems. The Canadian startup 'BlueDot' has developed an AI enable framework that precisely perceives the risk of the infection and level of hazard in a demographic region (Bluedot 2020). On a similar note, the healthcare analytics and solution corporation 'Cotiviti' is now using AI and fitness data to predict future coronavirus hot spots around the USA (TechRepublic 2020). To forecast the possible infection hubs, an AI model that computes the data based on Susceptible-Infected-Recovered-Dead (SIRD) protocol was used in Hubei, China (ET Healthworld 2020). Meanwhile, there are a lot more technologies that are under

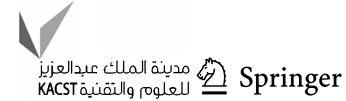


development process and yet to come in support of dealing with pandemic situations like coronavirus.

\section{Al working on coronavirus medication}

Artificial intelligence and data science have become critically important in pandemic situations such as COVID19. Google's 'Deep Mind' division has used its latest AI algorithms to understand the proteins and genetics of the coronavirus (ZD Net 2020). It has published its findings to help others develop treatments and understand more about the virus. 'BenevolentAI' has been using AI models to develop drugs that can cure the most challenging diseases and even putting efforts to medicate COVID-19. With the help of the AI module within the initial weeks of the pandemic itself, it proposed prevailing drugs that might be useful in curing coronavirus infection (Benevolent 2020). The supercomputers and cloud computing resources around the world are being employed to ventures possible breakthrough in the development of coronavirus vaccine. These systems can run calculations and model solutions at a much faster rate than standard computer processing. $\mathrm{Ke}$ et al. used AI to test and specify already existing drugs with positive effects against coronavirus (Ke et al. 2020). Continuous efforts are going on to establish clinically achievable permissible doses against SARS-CoV- 2.

\section{Pandemic tackling mobile applications}

Since the commencing of COVID-19 pandemic, many smartphone Apps have been developed, some of them operate through public authorities and others in collaboration with private companies. Worldwide governments and agencies are relying on smartphone Apps to provide contemporary coronavirus information, monitor quarantine of people, give healthcare services, and assist self-assessment. Based on the task which they perform, mobile Apps can be classified into information Apps, selfassessment Apps, and contact tracing Apps.

\section{Informational apps}

These Apps do not require a great deal of customization as they are meant to provide information rather than to interact. These applications give the latest information related to COVID-19 like breaking news, fact sheets, and guidelines, etc. Table 2 summarizes the list of informational mobile Apps used by various countries in coronavirus pandemic.

\section{Self-assessment apps}

COVID-19 self-assessment Apps for mobile phone helps people to evaluate their health and receive instructions/recommendations on COVID-19. The aim is to offer a degree of understanding to people, who seem to have infection symptoms and favor ailment through an easy set of questions. It also acts as a tool to educate people on how this disease spreads and guides them with preventive measures. The secondary objective is to lessen the flooding of health care centers with people having minor symptoms. Table 3 summarizes the list of self-assessment apps used by various countries during coronavirus pandemic.

\section{Contact tracing apps}

Contact tracing and warning has played an important role in all phases of the outbreak. The purpose of contact tracing and warning is to point out infection suspected person and ask them to self-quarantine or isolate if they show symptoms. The contact tracing also helps in aggregated facts to monitor infection spreading patterns in society. The various contact tracing Apps work on technology like Bluetooth specification, cryptography specification, and application program interface (API) framework. The Chinese authorities have developed a monitoring App known as 'Health Code' that performs massive statistics to figure out the level of risk associated with the person (Business Insider 2020). The Indian authorities have launched a smartphone App known as 'Aarogya Setu' to assist coronavirus patients and provide statistical data on the number of infected person in close vicinity of the user (Google Play 2020h). The 'CovidSafe' App launched by Australia approves the fitness of the users and gathers data to confirm whether they have come in contact with an infected person (Australian Government Department of Health 2020b). As the outbreak of COVID19 is escalating across the world, the number of software employed for contact tracing will also increase across the nations. The brief detail of contact tracing Apps used by different countries is listed in Table 4.

\section{Technology-based X-ray and CT image analysis}

One emerging solution to fasten the medical treatment is AI-driven image analysis. During COVID-19 infection screening and treatment, a large number of X-ray and computed tomography (CT) images are taken, and manually analyzing these images requires terrific effort. Under the context, AI can help via quantitative analysis and adjusting treatment plans according to reports of the patient. COVID19 detection neural network (COVNet) is a deep learning 
Table 2 Informational mobile Apps used by various countries in the COVID-19 pandemic

\begin{tabular}{|c|c|c|c|}
\hline Country & Application name & Function & References \\
\hline Bolivia & Bolivia Segura & $\begin{array}{l}\text { The latest updates of professional communications, statistics } \\
\text { on care, prevention, symptoms of disease and emergency } \\
\text { numbers, etc. are being provided via this App }\end{array}$ & Google Play (2020a) \\
\hline Brazil & Coronavírus-SUS & $\begin{array}{l}\text { The App is launched by the Brazilian Ministry of Health to } \\
\text { unfold recognition among humans about the outbreak }\end{array}$ & Google Play (2020b) \\
\hline Cambodia & Khmer Education COVID-19 App & $\begin{array}{l}\text { The Ministry of Education, Youth and Sport has launched } \\
\text { a competition to inspire public and students to send data } \\
\text { about the virus }\end{array}$ & The Phnom Penh Post (2020) \\
\hline Cuba & InfoCU & $\begin{array}{l}\text { The Ministry of Health has launched this App to supply resi- } \\
\text { dents with applicable data about the COVID-19 pandemic }\end{array}$ & CubApk (2020) \\
\hline Guatemala & COVID-19 en Guatemala & $\begin{array}{l}\text { Institute of Research and Projection for Science and Technol- } \\
\text { ogy (Incyt) and Rafael Landívar University developed } \\
\text { the tool to update data on the number of infected persons, } \\
\text { deaths and recovered people, etc. }\end{array}$ & PlazaPublica (2020) \\
\hline India (Kerala) & GoK direct & $\begin{array}{l}\text { The App presents formal information of the pandemic in a } \\
\text { particular region }\end{array}$ & Google Play (2020c) \\
\hline Indonesia & PikobarJawa Barat & $\begin{array}{l}\text { The App is beneficial for residents to request logistical help } \\
\text { and get entry to emergency, etc. }\end{array}$ & Google Play (2020d) \\
\hline Mauritius & beSafeMoris & $\begin{array}{l}\text { The App provides users a real-time statistics, obtained from } \\
\text { health organizations. Users can assist recommendations and } \\
\text { locate a list of various fitness centers }\end{array}$ & Google Play (2020e) \\
\hline Namibia & Covid-19 Namibia & $\begin{array}{l}\text { The Namibia University of Science and Technology (NUST) } \\
\text { designed an internet site and App for providing records } \\
\text { related to COVID-19 disruption }\end{array}$ & NUST (2020) \\
\hline Portugal & Estamos ON & $\begin{array}{l}\text { Application updates the country's epidemiological bulletin, } \\
\text { news related to government's feedback on pandemic }\end{array}$ & Google Play (2020f) \\
\hline Vietnam & NCOVI & $\begin{array}{l}\text { The Ministry of Health and The Ministry of Information and } \\
\text { Communications have launched an App to notify the coro- } \\
\text { navirus statistical data and other essential information }\end{array}$ & Google Play $(2020 \mathrm{~g})$ \\
\hline
\end{tabular}

algorithm-based AI module that screens the CT images to diagnose the coronavirus infection in patients ( $\mathrm{Li}$ et al. 2020). Figure 4 shows a schematic of pre-trained models that analyze the X-ray images to differentiate between COVID19-infected persons and normal person (Narin et al. 2020). Another deep learning framework based on the concatenation of three dimensional CNN ResNet-18 network (He et al. 2016) and location-attention method is proposed to analyse pulmonary CT images for identifying COVID-19 infection (Butt et al. 2020). A company named Infervision has developed an AI-based platform that helps healthcare people to effectively screen out the suspected individuals (ITN 2020a). Alibaba an e-commerce company has built an AI-enabled analysis machine that is estimated to be $96 \%$ correct in figuring out the virus-infected person (Technology Org 2020). A gadget named 'Coronavirus Chest CT Smart Evaluation System' developed in Shanghai can diagnose the suspected persons within seconds (Synced 2020). Wang et al. developed a clinical diagnosis for COVID-19 by employing a deep learning method to monitor radiographical deviation in CT-scan images with a comparison accuracy of 89.5\% (Wang et al. 2020). Yuan et al. examined the CT-scan images of coronavirus infected persons and analyzed them to be associated with the mortality of the sufferer (Yuan et al. 2020). Companies like Thirona and Delft Imaging have collectively developed a CAD4COVID screening platform built on the CAD4TB software for screening of COVID-19 (ITN 2020b). In line with the work described above, a list of research applying deep learning for COVID-19 prognosis is given in Table 5 .

\section{Mask technology}

To control the spread of respiratory infection, use of face masks by patients is a well-recognized strategy. The asymptomatic patients in SARS-CoV-2 are unaware of their infection and become active carriers of the infection. During breathing and talking, the resultant aerosol dispersion and droplets becomes the prime route of transmission. Thus, to prevent the spread and inhalation of these droplets, it is recommended to use the mask in public. Surgical masks are effective in preventing from spray and inhalation of droplets in the range above $5 \mu \mathrm{m}$, but have limited ability to filter submicron-sized droplets. Studies have shown that surgical masks and N95 are effective in intercepting respiratory

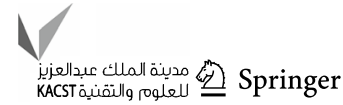




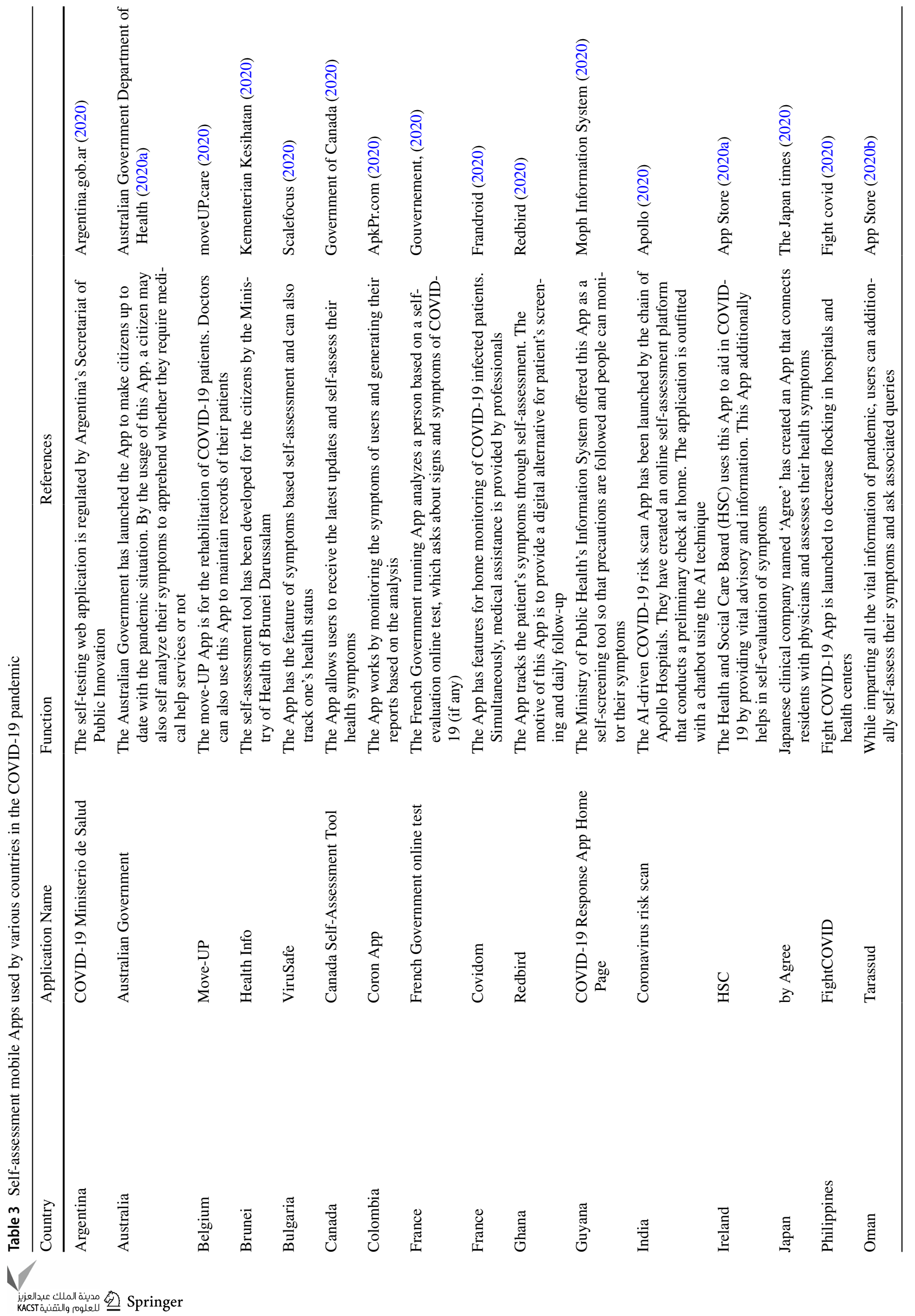




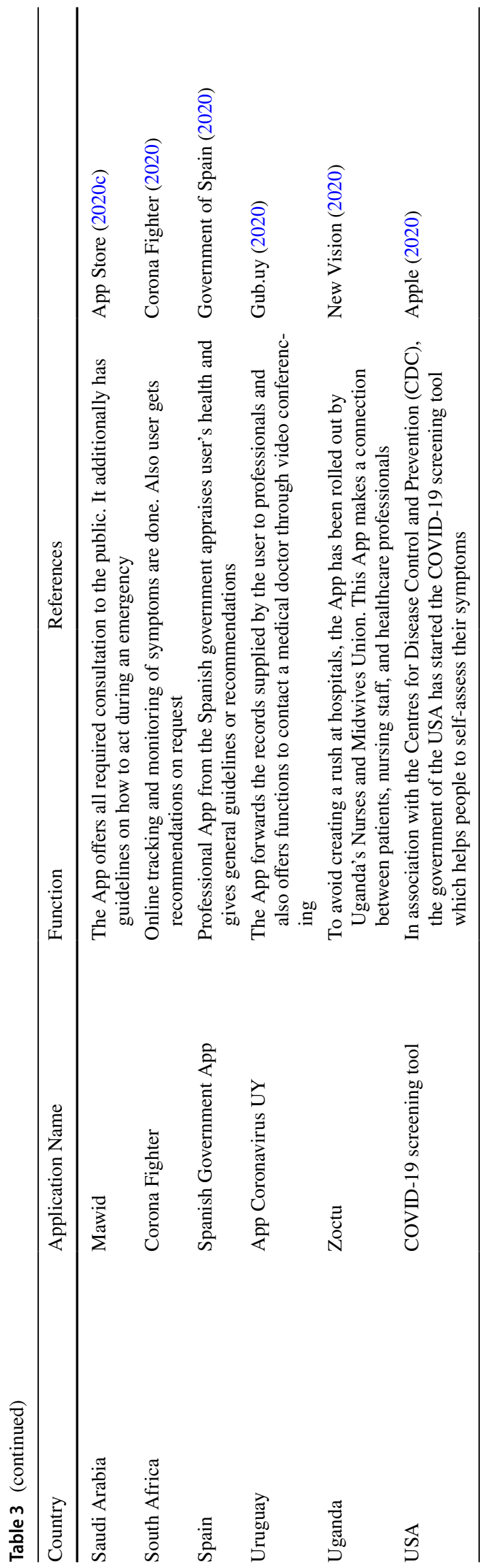

infection and can even prevent the spread of coronavirus through coughing. The European standard FFP2 and American standard N95 mask perform well as PPE, and are recommended for health workers dealing with sample collection and clinical care of COVID-19 patients. With an increase in the spread of the COVID-19, the global shortage of these PPE masks is a major concern. Thus, research is much focused on implementing the reuse of masks through disinfection methods and even to fabricate a cost-effective mask with self-disinfecting properties. Recently, Schwartz et al. adopted hydrogen peroxide vapor exposure as a method to decontaminate N95 mask and powered-air purifying respirators (PAPRs) masks, as shown in Fig. 5a. The study revealed that even after 50 cycles of disinfection, the N95 respirators retain their filtering capability (Schwartz et al. 2020). It is well known that UVC exposure has the ability to disinfect the surface more efficiently compared to other exposure methods. On a similar note, a smart UVC treatment-based hygiene product is launched by 'Cleanbox Technology'. The patented technology is based on UVC treatment for disinfecting point of use protective products that are not feasible to clean by a solution-based process. The technology is capable to safely eliminate $99.99+\%$ of fungi, bacteria, and viruses within seconds (Clean Box 2020). In another study, scientists have developed a special self-disinfecting mask that can give enhanced protection against the virus. The mask contains $\sim 150 \mu \mathrm{m}$-thick outer porous coating of modified polysulfone material, and can kill the virus having a size of $\sim 60 \mathrm{~nm}$ and above (The Times of India 2020). A washable mask that would kill $99 \%$ of bacteria and viruses has already stepped into the market. Extensive research has been done by the University of Arizona to fabricate mask with the ability to neutralize all kinds of pathogens that come in contact with the mask surface. Moreover, these masks can be washed with soap and water up to 30 times and are effective for up to 2 years. The effectiveness of mask was tested against many viruses, including the nearest to COVID-19-the 229E coronavirus (The National 2020). In another study, Marchese et al. suggested the use of a special device to be applied to the patient face during upper endoscopy, and this can minimize the aerosolization at the time of treatment (see Fig. 5b) (Marchese et al. 2020). During this global revolution in mask technology, 3D printing has emerged as an attractive tool to produce mask with improved disinfecting efficiency and tailored designs for enhanced comfort. A 3D-printed unique film called 'Maya sticker' can be attached to a face mask to increase its protective capabilities, as shown in Fig. 5c. The 3D-printed sticker has nanoscale fibers coated with disinfectants that enhance the capture and neutralization of nanoscale particles, respectively (Breaking Defense 2020). Ishack et al. displayed how $3 \mathrm{D}$ printing can be used to make customize face masks. In the study, they showed how 3D laser scanning can be implemented to scan exact

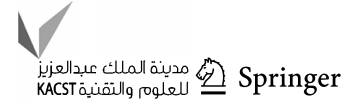


Table 4 Contact tracing Apps used by various countries in the COVID-19 pandemic

\begin{tabular}{|c|c|c|c|}
\hline Country & App Name & Function & References \\
\hline Austria & Stopp Corona & $\begin{array}{l}\text { The Austrian Red Cross and Uniqa-Stiftung have launched } \\
\text { a utility program to track humans that have come in } \\
\text { contact with Covid-19 carriers }\end{array}$ & Stopp Corona (2020) \\
\hline Brazil & DESVIRALIZE & $\begin{array}{l}\text { This online platform affords local monitoring for COVID- } \\
\text { 19. The application also indicates the symptoms of peo- } \\
\text { ple around the user and who are parts of their networks }\end{array}$ & Desviralize (2020) \\
\hline China & Health Code & $\begin{array}{l}\text { The utility lets in residents to check if they have been in } \\
\text { contact with a person identified with COVID-19. The } \\
\text { user is assigned with color QR code that indicates their } \\
\text { health status }\end{array}$ & Business Insider (2020) \\
\hline China: Hong Kong & StayHomeSafe & $\begin{array}{l}\text { Proposed software primarily tracks the contact of persons } \\
\text { associated with compulsory quarantine. If residents } \\
\text { are obliged to do the quarantine, they ought to put on a } \\
\text { wristband and setup the App }\end{array}$ & The Government of Honkong (2020) \\
\hline Cyprus & COVTRACER & $\begin{array}{l}\text { The software is capable to track infection carriers and } \\
\text { persons in contact with them }\end{array}$ & Rise Up (2020) \\
\hline Czechia & eRouška & $\begin{array}{l}\text { The software uses facts from the phones of COVID-19 } \\
\text { positive users and tracks their movement }\end{array}$ & Erouska (2020) \\
\hline France & Stop COVID & $\begin{array}{l}\text { The French authorities launched this App to track the indi- } \\
\text { viduals and limit the spread of COVID-19 by instructing } \\
\text { them at times }\end{array}$ & Techcrunch (2020) \\
\hline Ghana & GH Covid-19 tracker & $\begin{array}{l}\text { Tracking of individuals in close contact with infected } \\
\text { person is carried out through this App }\end{array}$ & News Ghana (2020) \\
\hline Germany & GeoHealthApp & $\begin{array}{l}\text { The App identifies individuals that have been in contact } \\
\text { with an infected person within past } 14 \text { days. A map } \\
\text { marks the region with excessive infection rates so that } \\
\text { users can take precautions }\end{array}$ & GeoHealthApp (2020) \\
\hline India & MahaKavach & $\begin{array}{l}\text { Maharashtra State Innovation Society developed an App } \\
\text { to manage COVID-19 through contact tracing of the } \\
\text { residents }\end{array}$ & SensorTower (2020) \\
\hline Israel & Hamagen & $\begin{array}{l}\text { Based on the details of the user, the App compares the } \\
\text { actions of a person recognized with COVID-19 }\end{array}$ & Google Play (2020i) \\
\hline Kazakhstan & Smart Astana & $\begin{array}{l}\text { This App consistently monitors the actions of the indi- } \\
\text { vidual in a quarantine period. Using the user's wherea- } \\
\text { bouts, the App additionally approves users to access } \\
\text { public services }\end{array}$ & Google Play (2020j) \\
\hline Norway & Smittestopp & $\begin{array}{l}\text { The Norwegian Institute of Public Health in collabora- } \\
\text { tion with regional company Simula, launched an App } \\
\text { for contact tracing. If an individual is found infected, } \\
\text { the software records can be used to point out persons in } \\
\text { close contact }\end{array}$ & Helsenorge.no (2020) \\
\hline Philippines & RC143 & $\begin{array}{l}\text { The Philippine Red Cross (PRC) has developed a portal } \\
\text { that uses geo-location for contact tracing. The idea is to } \\
\text { help users to stay away from the high-risk area }\end{array}$ & ABS-CBC News (2020) \\
\hline Poland & Home Quarantine & $\begin{array}{l}\text { The software is designed to monitor people returning } \\
\text { from abroad during their quarantine period. The App } \\
\text { requires reference pictures, phone numbers, and day to } \\
\text { day check-ins }\end{array}$ & Gov.pl (2020) \\
\hline Qatar & Ehteraz & $\begin{array}{l}\text { Qatar introduced an application that makes use of GPS } \\
\text { based technology and Bluetooth to tracks the movement } \\
\text { of users in quarantine }\end{array}$ & Gulf Times (2020) \\
\hline Singapore & TraceTogether & $\begin{array}{l}\text { The Singapore Ministry of Health, along with SG United } \\
\text { and GOVTECH Singapore, has launched this App to } \\
\text { track persons infected with COVID-19 }\end{array}$ & Tracetogether (2020) \\
\hline South Korea & $\begin{array}{l}\text { Corona } 100 \mathrm{~m} \\
\text { and } \\
\text { Corona Map }\end{array}$ & $\begin{array}{l}\text { The Korean App makes use of GPS to track quarantined } \\
\text { citizens. Get push notifications if the individual using the } \\
\text { App is } 100 \mathrm{~m} \text { away from the infected person }\end{array}$ & Android freeware (2020) \\
\hline
\end{tabular}


Table 4 (continued)

\begin{tabular}{|c|c|c|c|}
\hline Country & App Name & Function & References \\
\hline Thailand & MorChana & $\begin{array}{l}\text { This tool helps in contact tracing and prevents transmis- } \\
\text { sion especially to healthcare professionals }\end{array}$ & App Store (2020d) \\
\hline UK & (in development) NHSX & $\begin{array}{l}\text { The health service's digital transformation arm is develop- } \\
\text { ing an App to keep track of close contacts with infected } \\
\text { persons }\end{array}$ & NHSX (2020) \\
\hline UAE & Stay Home & $\begin{array}{l}\text { An App name 'Stay Home' is launched by the Ministry of } \\
\text { Health, Abu Dhabi. By monitoring the user's location, } \\
\text { their purpose is to maximize the gain of self-isolation } \\
\text { and curtail the spread of coronavirus infection }\end{array}$ & Emirates News Agency (2020) \\
\hline
\end{tabular}

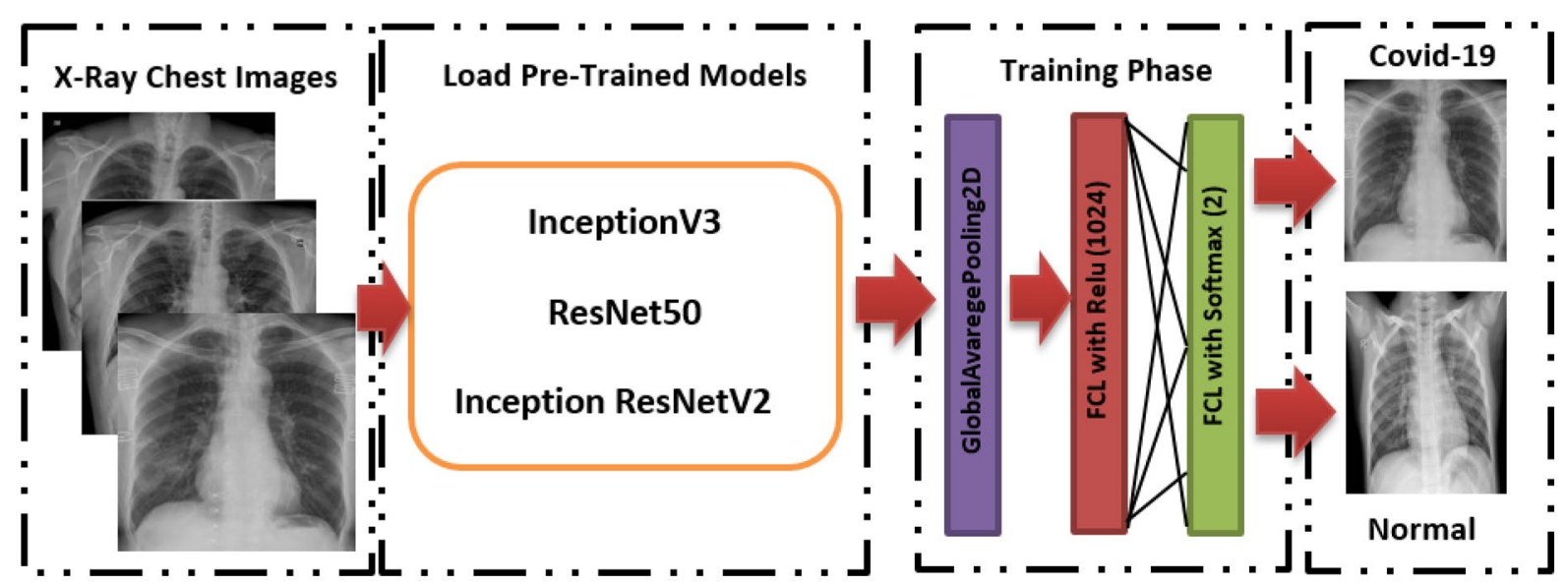

Fig. 4 Schematic representation of pre-trained models for the prediction of COVID-19 patients and the normal person (Narin et al. 2020)

facial parameters and how these parameters can be used to design an N95 mask template (Ishack and Lipner 2020). Even 3D-printed face mask is being developed that has ability to deactivate virus residing on its surface. The mask consists of copper nanostructure incorporated 3D-printed strips that has the ability to trap exhaled microbes (Medical Expo e-mag 2020; Copper 3D 2020). Figure 5d shows copper nanostructure and simulated design incorporated during $3 \mathrm{D}$ printing of the mask.

\section{Sensors}

Currently, the world is facing a pandemic situation caused by the spread of novel coronavirus. Worldwide organizations are doing a large number of tests to track the spread of SARS-CoV-2 and isolate infected persons. This highlights the importance of testing in this pandemic situation. Various diagnostic testing methods like qRT-PCR and serologic antibody tests, etc. are currently being used to confirm the coronavirus infection (Udugama et al. 2020). These diagnostic methods are precise, but require considerable time to confirm the test and are costly. Besides this, as these testing procedures require lab setup and technical staff, the number of tests conducted on daily basis is limited to certain fixed numbers. Knowing the fact that early detection of disease is a paramount for proper treatment of patients; researchers are working toward developing smart sensors for quick and instant detection of the infection. In response to tackle the coronavirus pandemic, worldwide scientist and various companies are developing a new point-of-care biosensors to detect coronavirus as soon as it is present in the human. Qiu et al. reported a plasmonic-based biosensor as a promising and alternative solution for the detection of COVID-19 infection (Qiu et al. 2020). A dual-functional sensor combines the localized surface plasmon resonance (LSPR) and plasmonic photothermal (PPT) sensing methods for diagnosis, as shown in Fig. 6a. The sensor has DNA receptor functionalized 2D gold nanoisland film that performs a sensitive detection through nucleic acid hybridization. The dual-functional LSPR biosensor can measure and determine SARS-CoV-2 sequences down to the concentration of 0.22 picomolar ( $\mathrm{pM})$, and can even precisely detect the specific target in a multigene mixture. In another optics-based detection method, an ultrasensitive laser sensor is proposed for the earliest point of infection detection within a minute. Here,

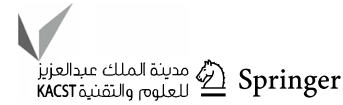


Table 5 List of research work applying deep mastering for COVID-19 prognosis using radiology image

\begin{tabular}{|c|c|c|c|}
\hline AI Technology & Data analysis & Results & References \\
\hline $\begin{array}{l}\text { A new } \mathrm{CNN} \text { and pre-trained } \\
\text { AlexNet with transfer learning }\end{array}$ & $\begin{array}{l}170 \text { X-ray images and } 361 \mathrm{CT} \text { images } \\
\text { of COVID-19 from } 5 \text { different } \\
\text { sources }\end{array}$ & $\begin{array}{l}\text { Accuracy of } 98 \% \text { on X-ray images and } \\
94.1 \% \text { on CT images }\end{array}$ & Maghdid et al. (2020a, b) \\
\hline ResNet-50 & $\begin{array}{l}\text { CT images obtained from } 157 \text { patients } \\
\text { (China and the U.S.A) }\end{array}$ & - & Gozes et al. (2020) \\
\hline COVNet & $\begin{array}{l}4,356 \text { chest CT tests from } 3,322 \text { suffer- } \\
\text { ers at } 6 \text { medical centers: } 1,296 \text { tests } \\
\text { for COVID-19, } 1,735 \text { for CAP and } \\
1,325 \text { for non-pneumonia }\end{array}$ & - & Li et al. (2020) \\
\hline $\begin{array}{l}\text { AlexNet, ResNet-18, } \\
\text { DenseNet-201, SqueezeNet }\end{array}$ & $\begin{array}{l}\text { 1,341 normal, 1,345 viral pneumonia } \\
\text { and } 190 \text { COVID-19 chest X-ray } \\
\text { images }\end{array}$ & Accuracy of $98.3 \%$ & Chowdhury et al. (2020) \\
\hline Re-trained ResNet-50 & $\begin{array}{l}\text { Chest X-ray pictures of } 50 \text { normal and } \\
50 \text { COVID-19 sufferers }\end{array}$ & Accuracy of $98 \%$ & Narin et al. (2020) \\
\hline $\begin{array}{l}\text { Drop-weights based } \\
\text { Bayesian CNNs }\end{array}$ & $\begin{array}{l}\text { 5,941 Posterior-anterior chest radiogra- } \\
\text { phy images across } 4 \text { classes (normal: } \\
\text { 1,583, bacterial pneumonia: } 2,786 \text {, } \\
\text { non- COVID-19 viral pneumonia: } \\
\text { 1,504, and COVID-19: } 68 \text { ) }\end{array}$ & Accuracy of $89.9 \%$ & Ghoshal and Tucker (2020) \\
\hline 2D deep $\mathrm{CNN}$ & $\begin{array}{l}970 \text { CT volumes of } 496 \text { COVID-19 } \\
\text { sufferers and } 1,385 \text { terrible instances }\end{array}$ & The efficiency of $94.98 \%$ & Jin et al. (2020) \\
\hline Multilayer perception and LSTM & $\begin{array}{l}\text { Clinical data and a series of chest CT } \\
\text { data were collected at different times } \\
\text { on } 133 \text { patients. Out of which } 54 \\
\text { patients progressed to severe/critical } \\
\text { periods }\end{array}$ & - & Bai et al. (2020) \\
\hline Shuai Wang & $\begin{array}{l}\text { Deep-learning method to extract the } \\
\text { COVID-19 radiographical modifica- } \\
\text { tions in CT-scan pictures to grant } \\
\text { prognosis }\end{array}$ & $\begin{array}{l}\text { Inside validation confirmed } 89.5 \% \\
\text { accuracy and exterior validation } \\
\text { achieved an accuracy of } 79.3 \%\end{array}$ & Wang et al. (2020) \\
\hline Delft Imaging and Thirona & $\begin{array}{l}\text { CAD4COVID is developed on identi- } \\
\text { cal technology as CAD4TB, which } \\
\text { has contributed to the screening of } \\
6 \text { million humans throughout } 40 \\
\text { international locations }\end{array}$ & - & ITN (2020b) \\
\hline
\end{tabular}

the test sample is saliva or nasal swab, which passes through receptors (like DNA strands and antibodies) that recognizes the antigens of the virus capsid. This intern results in the change of refractive index and laser light passing through the sample slightly change its travel direction. On comparing with the set of existing values, the change in light direction can be measured precisely with high sensitivity. The lower detection limit of the sensor lies in the range of pM to attomolar (aM) (EE news Europe 2020). A field-effect transistor (FET)-based biosensor for rapid detection of COVID-19 from human nasopharyngeal swab sample is reported by Seo et al. (see Fig. 6b) (Seo et al 2020). The sensor consists of SARS-CoV-2 spike protein sensitive antibodies that are coated on the surface of graphene sheets. The fabricated sensor could detect the virus concentrations of $1 \mathrm{fg} / \mathrm{mL}$ in phosphate-buffered saline. Also, the limit of detection in clinical samples is $2.42 \times 102$ copies $/ \mathrm{mL}$ and that in culture medium is $1.6 \times 101 \mathrm{pfu} / \mathrm{mL}$.
Another non-invasive point-of-care detection method is breath fingerprinting. The exhaled breath contains various gases and volatile organic compounds that can be used as a signature to detect the disease present in the human body. The breath fingerprinting has already been implemented in the detection of diseases like diabetes, liver infection, and renal infection, etc. By systematically analyzing the interaction mechanism of the coronavirus with the human cell and its effect on the biological activity of the body, it is possible to identify the new compound or compound whose proportion in the exhale breath is affected. Worldwide various companies are working on the detection of coronavirus by breath fingerprinting. On a similar note, a new hand held gas sensor for SARS-CoV-2 detection within a few seconds through exhaled breath fingerprinting is proposed by Nian Sun et al. (North Eastern University 2020). The proposed electrochemical sensor is expected to have several advantages like a fast response, low cost, ultra-high selectivity, and 

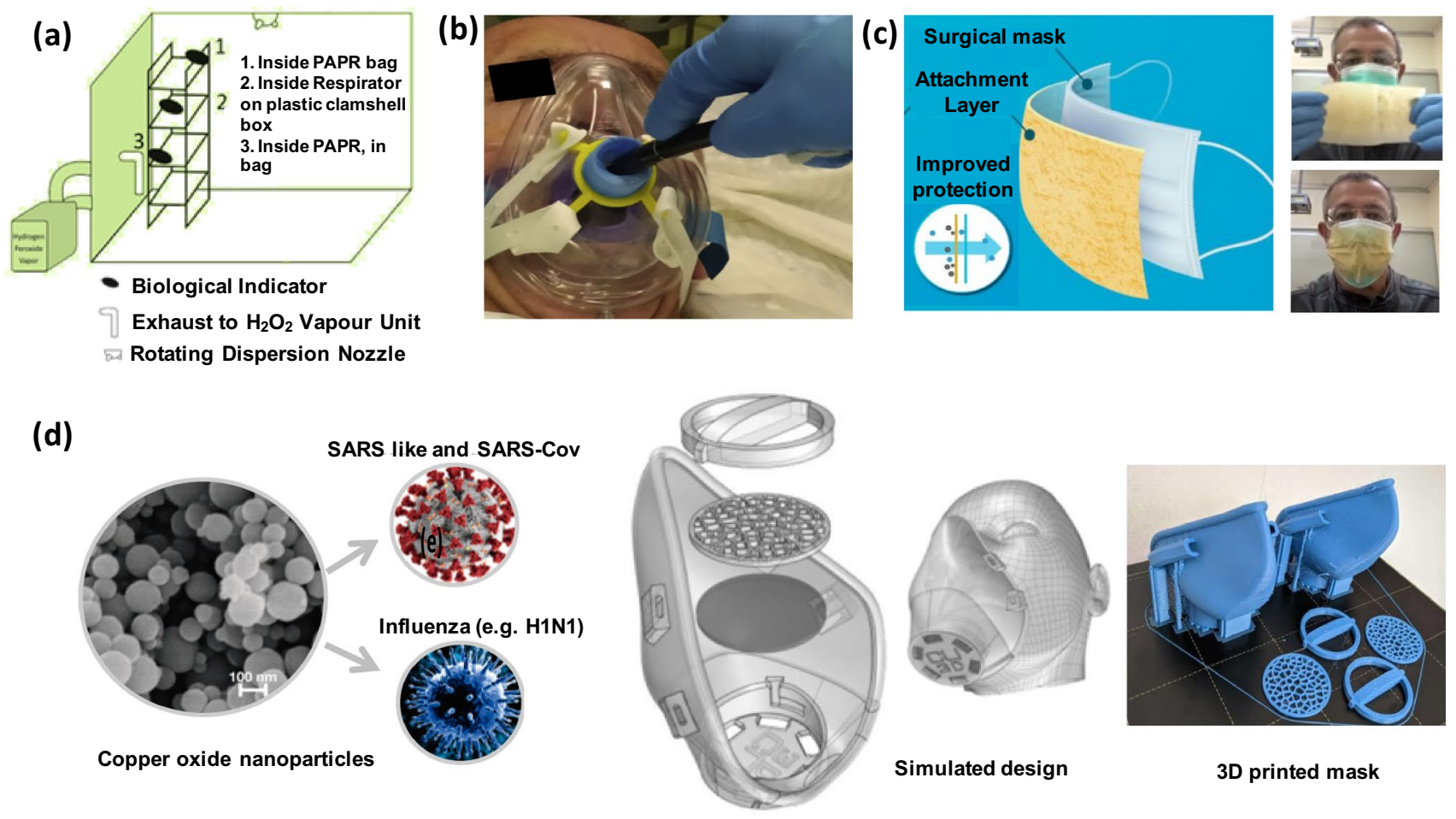

3D printed mask

Fig. 5 Mask technology during the COVID-19 pandemic. a Setup for disinfection of the mask using $\mathrm{H}_{2} \mathrm{O}_{2}$ vapors. The figure shows the placement of biological indicator at different sections of the disinfecting chamber (Schwartz et al. 2020). b A modified mask to be used during the upper endoscopy of patients (Marchese et al. 2020). c A

extreme sensitivity in the range of sub-part per quadrillion (sub-ppq). In a recent report, Next-Gen and Scentech Medical have jointly worked on a coronavirus detecting breathing device that can detect the virus infection (LabMedica 2020). Likewise, Grolltex develops a graphene-based virus testing platform for COVID-19 detection. The sensor employs functionalized gold nanoislands deposited on a monolayer graphene sheet. The sensor is fabricated on a plastic chip and requires a very small biological sample; as a result, it can perform 12 viral tests at a single time (GROLLTEX 2020). To aid in the fight and slow down the spread of infection, Vayyar, an Israel-based company, has developed a touchless remote monitoring sensor (HIT consultant 2020b). The intelligent sensors provide real-time monitoring of vital signs of COVID-19 symptoms which include respiratory rate, heart rate variability and pulse rate, etc. On a similar front, a tiny flexible throat sensor powered by AI technology that can track respiration rate, body temperature, and coughing is developed by researchers at Northwestern University in collaboration with the Shirley Ryan Ability Lab (Medgadget 2020). The device has to be stuck at the throat and assists in the continuous detection of any changes in the patient condition. Likewise, wearable sensors and IoT technologybased monitoring of COVID-19 patients are employed by unique porous self-disinfecting layer fabricated using a 3D printer, to be used as a sticker on any mask (Breaking Defense 2020). d Copper nanoparticles (left) and physical design (middle) used in the fabrication of 3D-printed mask along with copper nanoparticle incorporated 3D-printed face mask (right) (Copper 3D 2020)

the Shanghai Public Health Clinical Center SPHCC (Mobi Health News 2020). The technology helps to receive realtime patient data from the sensors and wirelessly transmit these data for continuous monitoring. Researchers at the University of Utah are working on a sensor that communicates with a smartphone through Bluetooth link and assists in the detection of COVID-19 (7 NEWS 2020). The sensor performs breath rate analyses and could also test swab containing samples when placed on the sensor. The test results will be displayed on a phone screen within a minute and the reusability of the sensor is ensured by disinfecting the sensor with small electric current. The smartphone gateway also adds features to send users test reports and location to concerned authorities.

\section{SWOT analysis of the technologies to tackle COVID-19}

The fourth industrial revolution has boosted globalization and seen an exponential growth in technology, which in turn played a critical role in advancing digital and manufacturing systems (AlMaadeed 2020). During coronavirus pandemic, already existing technologies and technologies under

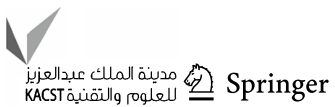


(a)

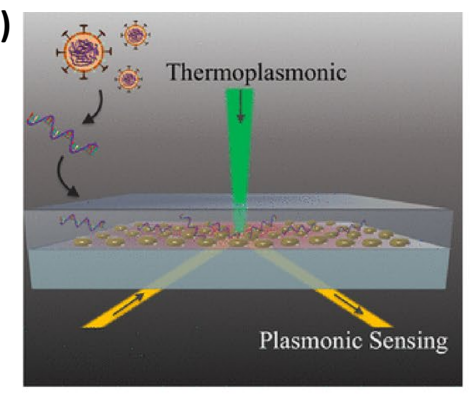

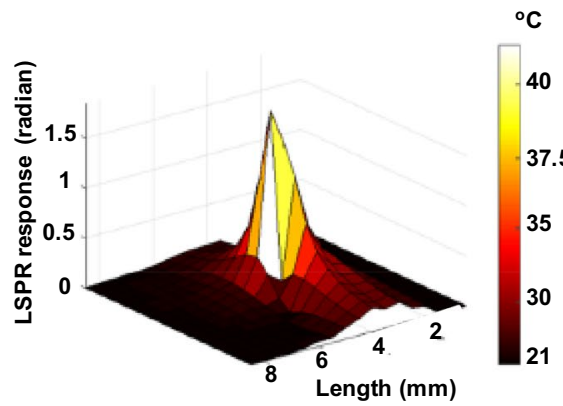

${ }^{\circ} \mathrm{C}$
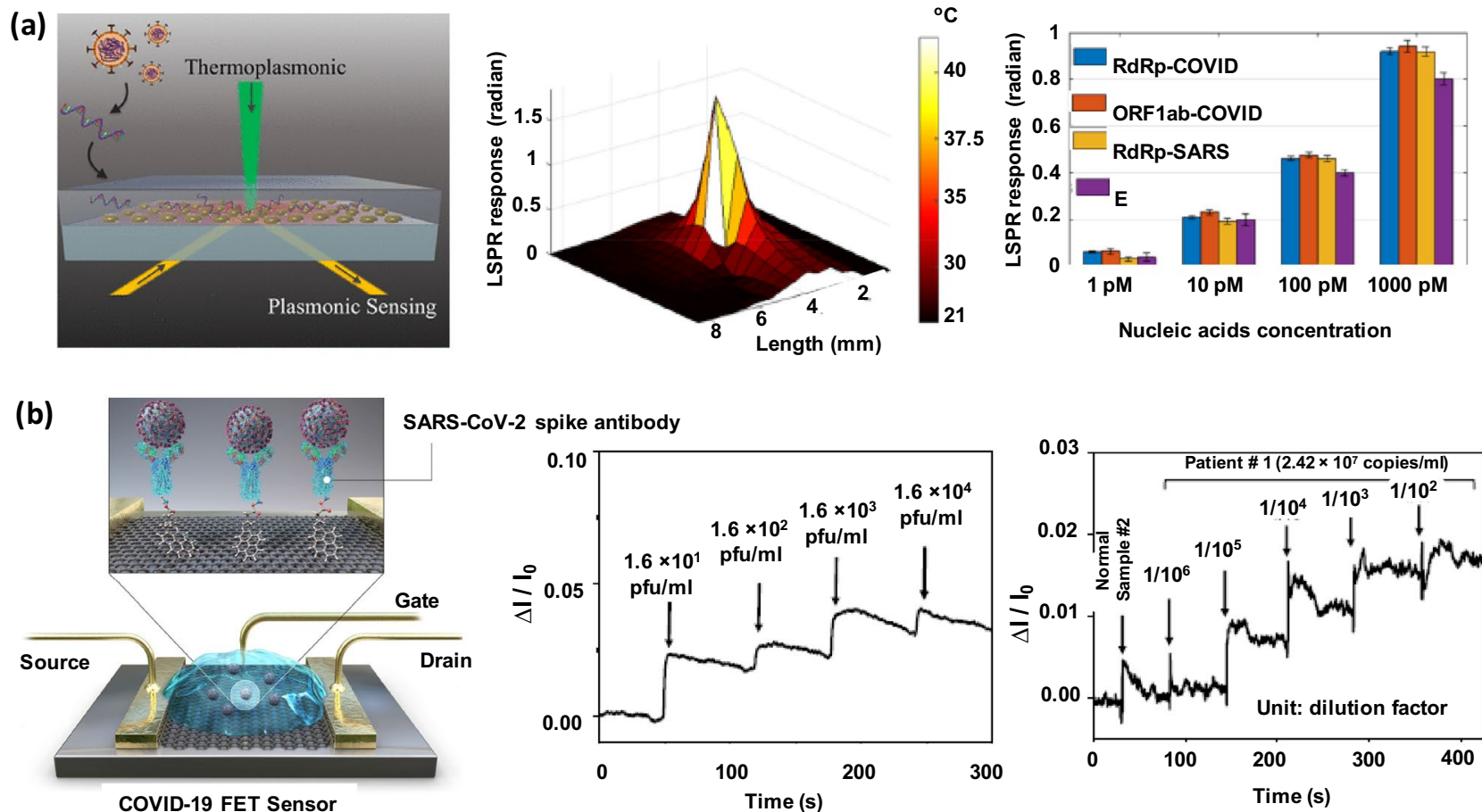

SARS-CoV-2 spike antibody
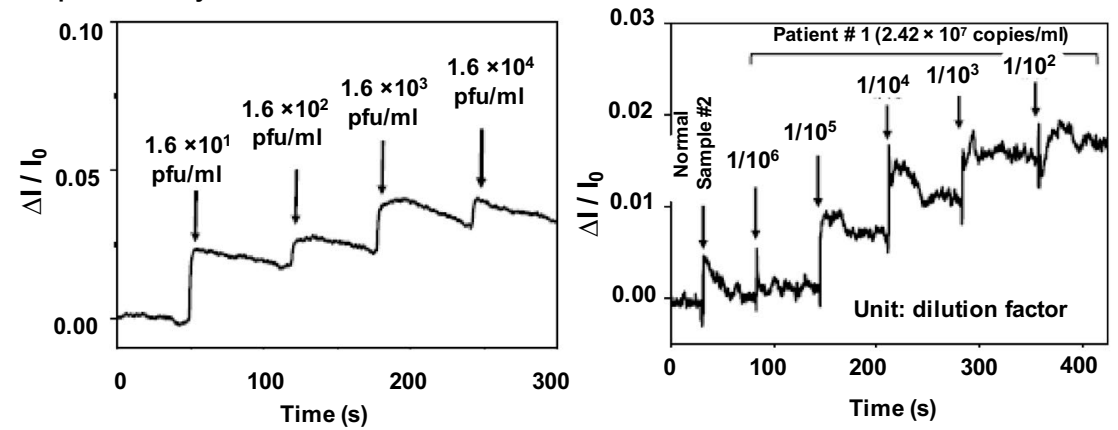

Fig. 6 Sensors for COVID-19 detection. a Schematic diagram of the COVID-19 plasmonic sensor (left). Mapping of temperature distribution around the PPT heat source (middle). Concentrations of various viral oligos measured using the dual-functional LSPR bio-

sensors (right) (Qiu et al. 2020). b Schematic diagram of the FET sensor (left). Real-time response of fabricated FET toward SARSCoV-2 cultured virus (middle). Real-time response of FET toward the SARS-CoV-2 clinical sample (right) (Seo et al. 2020)

development have aligned themselves to meet the demands and tackle the health emergency. In the context technological progress is skipping development stages and advancing at a much faster rate. This provides great strength and opportunities to solve issues concerning pandemic, but has some weakness which may directly or indirectly posse adverse effects in long terms. Figure 7 represents the strength, weakness, opportunity, and threats that technological progress in COVID-19 can pose in the near future. The main strength that technologies have provided in COVID-19 is the development of a strong health emergency system. The healthcare services have swiftly been tailored to increase their patient handling ability, and also the telehealth system is improved to increase the interaction capacity and reduce the workload. Moreover, the development of new testing methods and technology-driven diagnosis facilitates bulk testing in the pandemic situations.

Crisis may happen and impose immediate challenges, and to be sustainable, it is important to develop technologies that has long-term effectiveness. Lack of long-term vision and the absence of a continuity plan for these technologies could potentially be a weakness on the economic front. Even the effectiveness of various technologies involved in tackling the coronavirus outbreak has not been evaluated. Thus, there is an urgent need for regulations and standardizations of technologies that are being used in infection control systems.

The involvement of technology in people's life has increased during a pandemic; this might change their perception and response toward the use of technology in the near future. The pandemic has created a lot of challenges, which inter has generated opportunities, especially in the technology sector. While providing health services and contact tracing, authorities are collecting a huge amount of data related to their citizens, which imposes a serious concern for cyber security. This is one of the major threats that have been created, while it also creates opportunities for cyber security providing companies to enter the market and deliver solutions to government. Moreover, to ensure continuity, industries have been forced to digitally transform and innovate technologies on an unprecedented basis. The role of technology in tackling coronavirus pandemic is unparalleled, but there is a need to have balance in considering the involvement of these innovations. The incorporated changes in the current pandemic situation might have an influence on how we will live and work in near future.

\section{Conclusion}

The emergence of COVID-19 has pushed the limits of technologies and accelerated innovations in every field. The support of technology in managing the pandemic 
Fig. 7 SWOT analysis of technological development during COVID-19 pandemic

\begin{tabular}{|c|c|}
\hline $\begin{array}{l}\text { Strengths } \\
\text { Health emergency system is advancing } \\
\text { comprehensively. } \\
\text { Technology has improved the reach of } \\
\text { facilities to masses. } \\
\text { Quick and effective cooperation for } \\
\text { handling large scale surveillance. } \\
\text { Integration of smart technologies with } \\
\text { health and information system. } \\
\text { Construction of health emergency culture } \\
\text { and code of conduct system. }\end{array}$ & $\begin{array}{l}\text { Weakness } \\
\text { The public are flustered and feel bounded } \\
\text { with technology. } \\
\text { Lack of long term vision and absence of } \\
\text { technology continuity plan. } \\
\text { Technologies effectiveness in pandemic } \\
\text { situation is yet to be established. } \\
\text { Start up has low financial stability and over } \\
\text { dependence on capital sources. } \\
\text { Lack of face to face interaction can make } \\
\text { things harder to achieve. }\end{array}$ \\
\hline $\begin{array}{l}\text { Opportunities } \\
\text { New technological exploration. } \\
\text { Technological improvement to response in } \\
\text { health emergency system. } \\
\text { People safety orientated policies. } \\
\text { Strengthen public and technology } \\
\text { coordination to respond in emergencies. } \\
\text { Advance technology for cyber security. } \\
\text { Technology assisted International and } \\
\text { domestic linkages to tackle emergencies. }\end{array}$ & $\begin{array}{l}\text { Threats } \\
\text { Technologies impact on the daily life, work, } \\
\text { and psychology of the public. } \\
\text { Impact on the national economy. } \\
\text { Constant surveillance poses serious risk on } \\
\text { human rights. } \\
\text { Cyber crime poses real threat on security } \\
\text { of individuals data and other services. } \\
\text { Over dependence on technology can result } \\
\text { in power shift to tech companies. }\end{array}$ \\
\hline
\end{tabular}

situation is irreplaceable. The modifications in already existing drone, robotics, and artificial intelligence technology along with the framework in which they are applied to combat the pandemic situation have been discussed in detail. The findings establish how the smartphone applications that connect large masses can be configured to tackle emergency situations. The review gives deep insight on new innovations in the mask and sensor technology that has been globally investigated during the course of pandemic. A broader picture of how the various technologies are implemented and changes that they have undergone across the globe to directly or indirectly assist in the pandemic situation is represented. Alongside, the impact of these technologies on society in numerous aspects has been summarized. Thus, the finding helps in understanding the impact of the technology on the society and how these innovations can further be tuned to response in an emergency situation.

Acknowledgements This work was carried by the RRC grant \# RRC2-063 from the Qatar National Research Fund (a member of Qatar Foundation). The statements made herein are solely the responsibility of the authors.

\section{Compliance with ethical standards}

Conflict of interest On behalf of all authors, the corresponding author states that there is no conflict of interest.

\section{References}

ABS-CBC NEWS (2020) Red Cross uses RC143 mobile app to fight COVID-19. https://news.abs-cbn.com/news/04/07/20/philippine s-coronavirus-covid19-red-cross-mobile-app-rc143. Accessed 28 June 2020

Agostini M, Moja L, Banzi R, Pistotti V, Tonin P, Venneri A, Turolla A (2015) Telerehabilitation and recovery of motor function: a systematic review and meta-analysis. J Telemed Telecare 21:202213. https://doi.org/10.1177/1357633X15572201

Allam Z, Jones DS (2020) On the coronavirus (COVID-19) outbreak and the smart city network: universal data sharing standards coupled with artificial intelligence (AI) to benefit urban health monitoring and management. Healthcare 8:46-54. https://doi. org/10.3390/healthcare 8010046

AlMaadeed MA (2020) Emergent materials and industry 4.0 contribution toward pandemic diseases such as COVID-19. Emerg Mater 3:107-108. https://doi.org/10.1007/s42247-020-00102-4

Alsuliman T, Humaidan D, Sliman L (2020) Machine learning and artificial intelligence in the service of medicine: necessity or potentiality? Curr Res Transl Me. https://doi.org/10.1016/j.retra m.2020.01.002InPress

Android Freeware (2020) Corona 100m. https://www.androidfreeware .net/download-corona-100m.html. Accessed 2 July 2020

ApkPr.com (2020) CoronApp-Colombia. https://apkpr.com/fr/app/ co.gov.ins.guardianes. Accessed 2 July 2020

Apollo (2020) Coronavirus cough and risk scan. https://covid.apoll o247.com/. Accessed 2 July 2020

App Store (2020a) COVID-19 NI. https://apps.apple.com/gb/app/covid -19-ni/id1504120600. Accessed 29 June 2020

App Store (2020b) Tarassud. https://apps.apple.com/us/app/tarassud/ id1502105746. Accessed 29 June 2020 
App Store (2020c) Mawid. https://apps.apple.com/us/app/mawid -\%D9\%85\%D9\%88\%D8\%B9\%D8\%AF/id1295059205. Accessed 2 July 2020

App Store (2020d) MorChana. https://apps.apple.com/th/app/morch ana-\%E0\%B8\%AB\%E0\%B8\%A1\%E0\%B8\%AD\%E0\%B8\%8A\% E0\%B8\%99\%E0\%B8\%B0/id1505185420. Accessed 2 July 2020

Apple (2020) COVID-19 Screening Tool. https://www.apple.com/covid 19/. Accessed 29 June 2020

Argentina.gob.ar (2020) COVID-19 Ministerio de Salud. https://www. argentina.gob.ar/aplicaciones/coronavirus. Accessed 29 June 2020

Australian Government Department of Health (2020a) Coronavirus Australia app. https://www.health.gov.au/resources/apps-andtools/coronavirus-australia-app. Accessed 2 July 2020

Australian Government Department of Health (2020b) COVIDSafe app. https://www.health.gov.au/resources/apps-and-tools/covid safe-app. Accessed 2 July 2020

Bai X, Fang C, Zhou Y (2020) Predicting COVID-19 malignant progression with AI techniques. MedRxiv. https://doi. org/10.1101/2020.03.20.20037325

BBC (2020a) Coronavirus: China's Tech Fights Back. https://www. bbc.com/news/technology-51717164. Accessed 26 June 2020

BBC (2020b) Drone-to-door medicines trial takes flight in Ireland. https://www.bbc.com/news/technology-52206660. Accessed 26 June 2020

BBC (2020c) Coronavirus: Drones to deliver NHS supplies to Isle of Wight. https://www.bbc.com/news/technology-52419705. Accessed 28 June 2020

Benevolent (2020) Publications. https://www.benevolent.com/research. Accessed 30 June 2020

Bloomberg (2020)The health-care Startup that's fast-tracking drone delivery. https://www.bloomberg.com/news/articles/2020-0325/the-health-care-startup-that-s-fast-tracking-drone-delivery. Accessed 4 July 2020

Bluedot (2020) BlueDot's outbreak risk software safeguards lives by mitigating exposure to infectious diseases that threaten human health, security, and prosperity. https://bluedot.global/. Accessed 2 July 2020

Breaking Defense (2020) COVID-19: Israel Deploys New Mask \& C2 Technologies. https://breakingdefense.com/2020/04/covid -19-israel-deploys-new-mask-c2-technologies/. Accessed 30 June 2020

Business Insider (2020) China is reportedly making people download an Alibaba-backed app that decides whether they'll be quarantined for coronavirus. https://www.businessinsider.com/ alibaba-coronavirus-chinese-app-quarantine-color-code-20203 ? $r=U S \& I R=T$. Accessed 28 June 2020

Butt C, Gill J, Chun D, Babu BA (2020) Deep learning system to screen coronavirus disease 2019 pneumonia. Appl Intell 22:1-7. https ://doi.org/10.1007/s10489-020-01714-3

Carriere J, Fong J, Meyer T, Sloboda R, Husain S, Usmani N, Tavakoli M (2019) An admittance-controlled robotic assistant for semiautonomous breast ultrasound scanning. Int Sympos Med Robot. https://doi.org/10.1109/ISMR.2019.8710206

Chang SL, Harding N, Zachreson C, Cliff OM, Prokopenko M (2020) Modelling transmission and control of the COVID-19 pandemic in Australia.

China Daily (2020) Eyes in the sky helping fight pandemic. https:// www.chinadaily.com.cn/a/202004/16/WS5e97bdcba3105d50a3 d169b1.html. Accessed 2 July 2020

Chowdhury ME, Rahman T, Khandakar A et al (2020) Can AI help in screening viral and COVID-19 pneumonia? https://arxiv.org/ abs/2003.13145

Clay and Milk (2020) Rantizo is using drone technology to sanitize stadiums. https://clayandmilk.com/2020/04/28/rantizo-is-using -drone-technology-to-sanitize-stadiums/. Accessed 28 June 2020
Clean Box (2020) CleanDefense. https://www.cleanboxtech.com/ cleandefense. Accessed 30 June 2020

Cliff OM, Harding N, Piraveenan M, Erten EY, Gambhir M, Prokopenko M (2018) Investigating spatiotemporal dynamics and synchrony of influenza epidemics in Australia: an agent-based modelling approach. Simul Model Pract Theory 87:412-431. https://doi.org/10.1016/j.simpat.2018.07.005

Copper 3D (2020) Antimicrobial 3d printing and active materials. https://www.3dprintlife.com/medical-grade-filament/plactivean 1 . Accessed 3 July 2020

Corona Fighter (2020) Covid-19 symptom assessment. https://www. testforcovid.co.za/. Accessed 2 July 2020

CubApk (2020)COVID-19-InfoCU. https://cubapk.com/store/cu.sld. COVID_19_InfoCU. Accessed 27 June 2020

Desviralize (2020) Desviralize.org is a voluntarily networked platform, offering local monitoring of the spread of COVID-19. https://desviralize.org/. Accessed 1 July 2020

Enterprise DJI (2020) Innovating to fight covid-19: four ways drones are contributing. https://enterprise.dji.com/news/detail/fight -covid-19-with-drones. Accessed 27 June 2020

Ecns.cn (2020) Robot dog enforcing social distancing in Singapore. http://www.ecns.cn/hd/2020-05-15/detail-ifzwknkv0960244 .shtml. Accessed 1 July 2020

EE News Europe (2020) Laser-based photonics test detects Covid-19 from saliva. https://www.eenewseurope.com/news/laser-based -photonics-test-detects-covid-19-saliva. Accessed 4 July 2020

Elavarasan RM, Pugazhendhi R (2020) Restructured society and environment: a review on potential technological strategies to control the COVID-19 pandemic. Sci Total Environ 725:138858-138875. https://doi.org/10.1016/j.scito tenv. 2020.138858

Emirates News Agency (2020) New 'Stay Home' App launched by DoH to reinforce self-quarantine procedures. http://wam.ae/en/ details/1395302834693. Accessed 3 July 2020

Erouska (2020) eRouška application. https://erouska.cz/. Accessed 2 July 2020

ERR.ee (2020) First ever drone flight carrying coronavirus patient sample in Estonia. https://news.err.ee/1081652/first-ever-drone -flight-carrying-coronavirus-patient-sample-in-estonia. Accessed 28 June 2020

ET Healthworld (2020) Studies use SIRD model to forecast COVID-19 spread. https://health.economictimes.indiatimes.com/news/indus try/studies-use-sird-model-to-forecast-covid-19-spread/74920 762. Accessed 2 July 2020

European Parliament (2020) Ten technologies to fight coronavirus. https ://www.europarl.europa.eu/RegData/etudes/IDAN/2020/641543/ EPRS_IDA(2020)641543_EN.pdf. Accessed 27 June 2020

Evening Standard (2020) Robots offer a contact-free way of getting swabbed for coronavirus. https://www.standard.co.uk/tech/ robots-offer-new-coronavirus-swab-technique-a4477396.html. Accessed 2 July 2020

FIERCE Electronics (2020) Drones to fly COVID-19 relief in parts of North Carolina. https://www.fierceelectronics.com/electronics/ drones-to-fly-vovid-19-relief-food-and-supplies-parts-north -carolina. Accessed 30 June 2020

Fight Covid (2020) Do I have COVID-19? Self Assessment Survey. https://fightcovid.app/. Accessed 2 July 2020

Fong J, Martinez C, Tavakoli M (2019) Ways to learn a therapist's patient-specific intervention: robotics-vs Telerobotics-mediated hands-on teaching. Int Conf Robot Autom. https://doi. org/10.1109/ICRA.2019.8793907

Forbes (2020) Could 'Pandemic Drones' help slow coronavirus? Probably not-but COVID-19 is a boom for business. https://www. forbes.com/sites/petertaylor/2020/04/25/could-pandemic-drone s-help-slow-coronavirus-probably-not-but-covid-19-is-a-boomfor-business/\#676276c662a4. Accessed 28 June 2020 
Frandroid (2020) Covidom. https://www.frandroid.com/telecharger/ apps/covidom. Accessed 29 June 2020

GeoHealthApp (2020) geoHealth Application. https://en.geohealtha pp.de/. Accessed 2 July 2020

Ghoshal B, Tucker A (2020) Estimating uncertainty and interpretability in deep learning for coronavirus (COVID-19) detection.

Google Play (2020a) Bolivia Segura. https://play.google.com/store /apps/details?id=com.agetic.coronaviru sapp\&hl=en_US. Accessed 28 June 2020

Google Play (2020b) Coronavírus-SUS. https://play.google.com/store /apps/details?id=br.gov.datasus.guardioes\&hl=en. Accessed 28 June 2020

Google Play (2020c) Gok Kerala. https://play.google.com/store/apps/ details?id=com.qkopy.prdkerala\&hl=en. Accessed 2 July 2020

Google Play (2020d) PIKOBAR Jawa Barat. https://play.google.com/ store/apps/details?id=id.go.jabarprov.pikobar\&hl=en. Accessed 2 July 2020

Google Play (2020e) beSafeMoris. https://play.google.com/store/apps/ details?id=mu.mt.healthapp. Accessed 2 July 2020

Google Play (2020f) Estamos ON-Covid19. https://play.google.com/ store/apps/details?id=com. vost.covid19mobile. Accessed 2 July 2020

Google Play (2020g) NCOVI. https://play.google.com/store/apps/detai ls?id=com.vnptit.innovation.ncovi\&hl=en. Accessed 2 July 2020

Google Play (2020h) Aarogya Setu. https:/play.google.com/store/apps/ details?id=nic.goi.aarogyasetu\&hl=en. Accessed 2 July 2020

Google Play (2020i) HaMagen (the sheild). https://play.google.com/ store/apps/details?id=com.hamagen $\&$ hl $=$ en. Accessed 2 July 2020

Google Play (2020j) Smart astana. https://play.google.com/store/apps/ details?id=kz.citysoft.smartastana\&hl=en. Accessed 2 July 2020

Gouvernement (2020) Covid-19. https://www.gouvernement.fr/infocoronavirus/orientation-medicale. Accessed 2 July 2020

Gov.pl (2020) The home quarantine application: the process of sharing it has started. https://www.gov.pl/web/cyfryzacja/aplik acja-kwarantanna-domowa--ruszyl-proces-jej-udostepniania. Accessed 2 July 2020

Government of Canada (2020) Canada COVID-19 app and self-assessment tool. https://ca.thrive.health/. Accessed 28 June 2020

Government of Spain (2020) COVID-19 self - assessment. https://asist encia.covid19.gob.es/. Accessed 2 July 2020

Gozes O, Frid-Adar M, Greenspan H, Browning P, Zhang H, Ji W, Bernheim A, Siegel E (2020) Rapid AI development cycle for the coronavirus (covid-19) pandemic: Initial results for automated detection \& patient monitoring using deep learning CT image analysis. arXiv:2003.05037

GPS WORLD (2020a) China fights coronavirus with delivery drones. https://www.gpsworld.com/china-fights-coronavirus-with-deliv ery-drones/. Accessed 1 July 2020

GPS World (2020b) Pandemic drones to monitor, detect those with COVID-19. https://www.gpsworld.com/draganfly-camera-anduav-expertise-to-help-diagnose-coronavirus/. Accessed 4 July 2020

GROLLTEX (2020) Graphene sensors in COVID-19 tests. https://groll tex.com/graphene-sensors-covid-19-tests/. Accessed 3 July 2020

Gub.uy (2020) Coronavirus national plan. https://www.gub.uy/minis terio-salud-publica/coronavirus. Accessed 2 July 2020

Gulf Times (2020) Ehteraz, new app to be launched soon to help enhance preventive measures against Covid-19. https://m.gulftimes.com/story/660433/Ehteraz-new-app-to-be-launchedsoon-to-help-enhance-preventive-measures-against-Covid-19 Accessed 25 June 2020

H2 view (2020) Coronavirus: Facemasks delivered by hydrogen-powered drone. https://www.h2-view.com/story/coronavirus-facem asks-delivered-by-hydrogen-powered-drone/. Accessed 3 July 2020
He K, Zhang X, Ren S, Sun J (2016) Deep residual learning for image recognition. In: Proceedings of the IEEE conference on computer vision and pattern recognition, pp 770-778. https://openaccess .thecvf.com/content_cvpr_2016/html/He_Deep_Residual_Learn ing_CVPR_2016_paper.html

Healthcare Packaging (2020) New robots perform COVID-19 swab tests. https:/www.healthcarepackaging.com/covid-19/artic le/21136422/quick-hits-new-robots-perform-covid19-swab-tests . Accessed 30 June 2020

Helsenorge.no (2020) Together we can fight coronavirus - Smittestopp temporarily deactivated. https://helsenorge.no/coronavirus/smitt estopp. Accessed 1 July 2020

HIT consultant (2020a) 'Pandemic Drone' could detect virus symptoms like COVID-19 in crowds. https://hitconsultant.net/2020/03/27/ pandemic-drone-could-detect-virus-symptoms-like-covid-19-incrowds/\#.Xv-7VigzY2x. Accessed 26 June 2020

HIT Consultant (2020b) Israeli government adopts touchless remote monitoring to detect COVID-19 symptoms. https://hitconsult ant.net/2020/04/16/israeli-government-adopts-touchless-remot e-monitoring-to-detect-covid-19-symptoms/\#.XvJnNZozbIV. Accessed 2 July 2020

$\mathrm{Hu}$ Z, Ge Q, Jin L, Xiong M (2020) Artificial intelligence forecasting of covid-19 in China, pp 1-14. arXiv:2002.07112

Inside Unmanned Systems (2020) DDC partners with GlobalMedic to service first nation community during coronavirus pandemic. https://insideunmannedsystems.com/ddc-partnerswith-globalmedic-to-service-first-nation-community-durin g-coron avirus-pandemic/?utm_source $=$ Airborne + Inter national+Response+Team+\%28AIRT\%29+News+Li\%20 t\&utm_campaign $=968$ ae 467 a 1 -EMAIL_CAMPA IGN_2020_06_21_12_26\&utm_mediu m=email\&utm_ term=0_2ecada6f57-968ae467a1-402412734 . Accessed 1 July 2020

International Airport Review (2020) Hamad Airport implements new technologies for post-COVID-19 era. https://www.internationalai rportreview.com/news/117582/hia-hamad-airport-preparationspost-covid19/. Accessed 30 June 2020

Intuitive (2020) Your surgeon in control. https://www.davincisurgery. com/da-vinci-systems/about-da-vinci-systems. Accessed 27 June 2020

Ishack S, Lipner SR (2020) Applications of 3D printing technology to address COVID-19 related supply shortages. Am J Med 133:771-773. https://doi.org/10.1016/j.amjmed.2020.04.002

ITN (2020a) Infervision in the frontlines against the coronavirus. https://www.itnonline.com/content/infervision-frontlines-again st-coronavirus. Accessed 4 July 2020

ITN (2020b) Dutch companies offer free innovative COVID-19 AI software. https://www.itnonline.com/content/dutch-companies-offer -free-innovative-covid-19-ai-software. Accessed 28 June 2020

Javaid M, Haleem A, Vaishya R, Bahl S, Suman R, Vaish A (2020) Industry 4.0 technologies and their applications in fighting COVID-19 pandemic. Diabetes Metab Syndr 14:419-422. https ://doi.org/10.1016/j.dsx.2020.04.032

Jin C, Chen W, Cao Y et al (2020) Development and evaluation of an AI system for COVID-19 diagnosis. medRxiv. https://doi. org/10.1101/2020.03.20.20039834

Karvekar SB (2019). Smartphone-based human fatigue detection in an industrial environment using gait analysis. https://scholarwor ks.rit.edu

Ke YY, Peng TT, Yeh TK (2020) Artificial intelligence approach fighting COVID-19 with repurposing drugs. Biomed J. https://doi. org/10.1016/j.bj.2020.05.001

Kementerian Kesihatan (2020) Ministry of Health. https://www. healthinfo.gov.bn/smart guide/user/login?callback=https $\% 3 \mathrm{~A} \% 2 \mathrm{~F} \% 2 \mathrm{Fw} w \mathrm{w}$.healthinfo.gov.bn $\% 2 \mathrm{~F} \% 23 \% 2 \mathrm{Fhome.}$ Accessed 28 June 2020

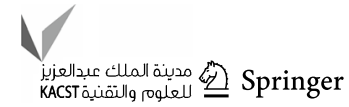


Kumar A, Gupta PK, Srivastava A (2020) A review of modern technologies for tackling COVID-19 pandemic. Diabetes Metab Syndr 14:569-573. https://doi.org/10.1016/j.dsx.2020.05.008

La Opinion (2020) Utilizan drones para llevar pruebas de coronavirus. https://laopinion.com/2020/04/29/utilizan-drones-para-lleva r-pruebas-de-coronavirus/. Accessed 27 June 2020

LabMedica (2020) coronavirus detecting breathing device could potentially give a diagnosis in less than one minute. https://www.labme dica.com/covid-19/articles/29427/coronavirus-detecting-breat hing-device-could-potentially-give-a-diagnosis-in-less-thanone-minute.html. Accessed 24 June 2020

Lai CC, Shih TP, Ko WC, Tang HJ, Hsueh PR (2020) Severe acute respiratory syndrome coronavirus 2 (SARS-CoV-2) and corona virus disease-2019 (COVID-19): the epidemic and the challenges. Int J Antimicrob Agents 55:105924-105932. https://doi. org/10.1016/j.ijantimicag.2020.105924

Li L, Qin L, Xu Z et al (2020) Using artificial intelligence to detect COVID-19 and community-acquired pneumonia based on pulmonary CT: evaluation of the diagnostic accuracy. Radiology 296:E65-E71. https://doi.org/10.1148/radiol.2020200905

Maghdid HS, Asaad AT, Ghafoor K.Z, Sadiq AS, Khan MK (2020a) Diagnosing COVID-19 pneumonia from X-ray and CT images using deep learning and transfer learning algorithms. arXiv :2004.00038

Maghdid HS, Ghafoor KZ, Sadiq AS, Curran K, Rabie K (2020b) A novel AI-enabled framework to diagnose coronavirus covid 19 using smartphone embedded sensors: Design study, pp 1-7. arXiv:2003.07434

Marchese M, Capannolo A, Lombardi L, Di Carlo M, Marinangeli F, Fusco P (2020) Use of a modified ventilation mask to avoid aerosolizing spread of droplets for short endoscopic procedures during coronavirus COVID-19 outbreak. Gastrointest Endosc 92:439-440. https://doi.org/10.1016/j.gie.2020.03.3853

Medgadget (2020) Flexible throat sensor powered by AI to track COVID-19 symptoms. https://www.medgadget.com/2020/05/ flexible-throat-sensor-powered-by-ai-to-track-covid-19.html. Accessed 1 July 2020

Medical Expo e-mag (2020) Covid-19: developing high tech protective masks. http://emag.medicalexpo.com/covid-19-development-ofhigh-tech-protective-masks/. Accessed 30 June 2020

Mirza M, Osindero S (2014) Conditional generative adversarial nets, pp 1-7. arXiv:1411.1784

Mishra B, Garg D, Narang P, Mishra V (2020) Drone-surveillance for search and rescue in natural disaster. Comput Commun 156:110. https://doi.org/10.1016/j.comcom.2020.03.012

Mobi Health News (2020) SPHCC employs IoT tech and wearable sensors to monitor COVID-19 patients. https://www.mobihealth news.com/news/asia-pacific/sphcc-employs-iot-tech-and-weara ble-sensors-monitor-covid-19-patients. Accessed 3 July 2020

Mohammed MN, Syamsudin H, Al-Zubaidi S, Yusuf E (2020) Novel COVID-19 detection and diagnosis system using IOT based smart helmet. J Psychosoc Rehabilit 24:2296-2303. https://doi. org/10.37200/IJPR/V24I7/PR270221

Moph Information System (2020) COVID-19 self screening. https ://covid19.health.gov.gy/apps/f?p=100:52:15173457806101. Accessed 2 July 2020

moveUP.care (2020) COVID-19. https://www.moveup.care/covid. Accessed 29 June 2020

Narin A, Kaya C, Pamuk Z (2020) Automatic detection of coronavirus disease (covid-19) using X-ray images and deep convolutional neural networks. arXiv:2003.10849

Nemati E, Rahman MM, Nathan V, Vatanparvar K, Kuang J (2019) A comprehensive approach for cough type detection. IEEE/ACMCHASE. https://doi.org/10.1109/CHASE48038.2019.00013

NEWS (2020) Researchers working on smartphone sensor to detect COVID-19. https://www.wwnytv.com/2020/05/11/researcher s-working-smartphone-sensor-detect-covid-/. Accessed 4 July 2020

News Ghana (2020) Ghana launches COVID-19 tracking app. https ://newsghana.com.gh/ghana-launches-covid-19-tracking-app/. Accessed 2 July 2020

New Vision (2020) COVID-19: nurses use app to reach patients. https ://www.newvision.co.ug/news/1517622/covid-19-nurses-appreach-patients Accessed 2 July 202.

Nguyen TT (2020) Artificial intelligence in the battle against coronavirus (COVID-19): a survey and future research directions. Preprint. https://doi.org/10.13140/RG.2.2.36491.23846

NHSX (2020) Driving forward the digital transformation of health and social care. https://www.nhsx.nhs.uk/. Accessed 4 July 2020

Nikkei Asian Review (2020a) JD.com makes drone deliveries as coronavirus cuts off usual modes. https://asia.nikkei.com/Spotlight/ Coronavirus/JD.com-makes-drone-deliveries-as-coronaviru s-cuts-off-usual-modes. Accessed 26 June 2020

Nikkei Asian review (2020b) Robots help China manage the coronavirus pandemic. https://asia.nikkei.com/Business/China-tech/ Robots-help-China-manage-the-coronavirus-pandemic. Accessed June 272020

North Eastern University (2020) Sensors to detect COVID-19 diagnosis instantly. https://coe.northeastern.edu/news/sensors-to-detec t-covid-19-diagnosis-instantly/. Accessed 2 July 2020

NUST (2020) NUST launches COVID-19 website and mobile app. https://www.nust.na/?q=news/nust-launches-covid-19-websiteand-mobile-app. Accessed 27 June 2020

OECD.AI (2020) AI-powered COVID-19 watch https://www.oecd.ai/ covid. Accessed 26 July 2020

PlazaPublica (2020) Sigue en vivo la evolución del COVID-19 con esta app de la Landívar. https://www.plazapublica.com.gt/conte nt/sigue-en-vivo-la-evolucion-del-covid-19-con-esta-app-de-lalandivar. Accessed 29 June 2020

Poljak M, Šterbenc A (2020) Use of drones in clinical microbiology and infectious diseases: current status, challenges and barriers. Clin Microbiol Infect 26:425-430. https://doi.org/10.1016/j. cmi.2019.09.014

Priye A, Wong S, Bi Y, Carpio M et al (2016) Lab-on-a-drone: toward pinpoint deployment of smartphone-enabled nucleic acid-based diagnostics for mobile health care. Anal Chem 88:4651-4660. https://doi.org/10.1021/acs.analchem.5b04153

Qiu G, Gai Z, Tao Y, Schmitt J, Kullak-Ublick GA, Wang J (2020) Dual-functional plasmonic photothermal zz for highly accurate severe acute respiratory syndrome coronavirus 2 detection. ACS Nano 14:5268-5277. https://doi.org/10.1021/acsnano.0c02439

Quantum systems (2020) Drone delivers Covid-19 tests to laboratory in less than seven minutes. https://www.quantum-syste ms.com/2020/06/04/drone-delivers-covid-19-tests-to-laboratory -in-less-than-seven-minutes/. Accessed 29 June 2020

Redbird (2020) How Covid-19 is developing in Ghana. https://app. redbird.co/auth/covid-19/get-started. Accessed 2 July 2020

Reuters (2020) Chilean seniors look to the sky for medicine and masks. https://uk.reuters.com/article/health-coronavirus-chile-drone/ chilean-seniors-look-to-the-sky-for-medicine-and-masks-idUKL $1 \mathrm{~N} 2 \mathrm{C} 817 \mathrm{~V}$. Accessed 25 June 2020

Rise Up (2020) COVTRACER. https://covid-19.rise.org.cy/en/ Accessed 28 June 2020

Roldán Jiménez C, Bennett P, Ortiz García A, Cuest Vargas AI (2019) Fatigue detection during sit-to-stand test based on surface electromyography and acceleration: a case study. Sensors 19:4202. https://doi.org/10.3390/s19194202

Salzburg Global Seminar (2020) Japan-India transformative technology network. https://www.salzburgglobal.org/multi-year-series/jittn html. Accessed 4 July 2020

Scalefocus (2020) Prevent and assist in the fight against COVID-19. https://virusafe.info/. Accessed 29 June 2020 
Schwartz A, Stiegel M, Greeson N et al (2020) Decontamination and reuse of N95 respirators with hydrogen peroxide vapor to address worldwide personal protective equipment shortages during the SARS-CoV-2 (COVID-19) pandemic. Appl Biosaf 25:67-70. https://doi.org/10.1177/1535676020919932

SensorTower (2020) Mahakavach. https://sensortower.com/android/ in/maharashtra-state-innovation-society/app/mahakavach/com. mahakavach/overview. Accessed 3 July 2020

Seo G, Lee G, Kim MJ et al (2020) Rapid detection of COVID-19 causative virus (SARS-CoV-2) in human nasopharyngeal swab specimens using field-effect transistor-based biosensor. ACS Nano 14:5135-5142. https://doi.org/10.1021/acsnano.0c02823

Simple Flying (2020) Doha hamad airport launches coronavirus helmets and disinfection robots. https://simpleflying.com/dohahamad-airport-launches-coronavirus-helmets-disinfection-robot s/. Accessed 29 June 2020

Singh RP, Javaid M, Haleem A, Suman R (2020) Internet of things (IoT) applications to fight against COVID-19 pandemic. Diabetes Metab Syndr 14:521-524. https://doi.org/10.1016/j. dsx.2020.04.041

STAT (2020) Surge in patients overwhelms telehealth services amid coronavirus pandemic. https://www.statnews.com/2020/03/17/ telehealth-services-overwhelmed-amid-coronavirus-pandemic/. Accessed 27 June 2020

Stopp Corona (2020) The app in the fight against coronavirus. https:// www.stopp-corona.at/. Accessed 29 June 2020

Story A, Aldridge RW, Smith CM et al (2019) Smartphone-enabled video-observed versus directly observed treatment for tuberculosis: a multicentre, analyst-blinded, randomised, controlled superiority trial. Lancet 393:1216-1224. https://doi.org/10.1016/ S0140-6736(18)32993-3

Supply Chaindive (2020) JD Logistics deploys autonomous shuttles, drones for last-mile deliveries in coronavirus quarantine zones. https://www.supplychaindive.com/news/jd-logistics-autonomous -drones-deliveries-coronavirus/571875/. Accessed 25 June 2020

Synced (2020) AI enables doctors to diagnose COVID-19 infection in seconds. https://syncedreview.com/2020/02/27/ai-enables-docto rs-to-diagnose-covid-19-infection-in-seconds/. Accessed 4 July 2020

Tao R, Ocampo R, Fong J, Soleymani A, Tavakoli M (2020) Modeling and emulating a physiotherapist's role in robot-assisted rehabilitation. Adv Intell Syst 2:1900181. https://doi.org/10.1002/ aisy. 201900181

Tavakoli M, Carriere J, Torabi A (2020) Robotics, smart wearable technologies, and autonomous intelligent systems for healthcare during the COVID-19 pandemic: an analysis of the state of the art and future vision. Adv Intell Syst 2:2000071. https://doi. org/10.1002/aisy.202000071

Techcrunch (2020) France is officially working on 'Stop Covid' contact-tracing app. https://techcrunch.com/2020/04/08/france-isofficially-working-on-stop-covid-contact-tracing-app/. Accessed 28 June 2020

Technology Org (2020) AI algorithm detects coronavirus infections in patients from CT scans with $96 \%$ accuracy. https://www.techn ology.org/2020/03/01/ai-algorithm-detects-coronavirus-infec tions-in-patients-from-ct-scans-with-96-accuracy/. Accessed 27 June 2020

TechRepublic (2020) Artificial intelligence is predicting coronavirus outbreaks before they start. https://www.techrepublic.com/artic le/artificial-intelligence-is-predicting-coronavirus-outbreaksbefore-they-start/. Accessed 1 July 2020

The Government of Honkong (2020) "StayHomeSafe" Mobile App User Guide. https://www.coronavirus.gov.hk/eng/stay-home-safe. html Accessed 2 July 2020

The Guardian (2020) Drone deliveries soar in rural Scotland during coronavirus outbreak. https://www.theguardian.com/ uk-news/2020/may/29/drone-deliveries-soar-in-rural-scotlandduring-coronavirus-outbreak. Accessed 30 June 2020

The Japan Times (2020) Free Japanese-language medical app offers advice about coronavirus. https://www.japantimes.co.jp/ news/2020/02/23/national/science-health/free-japanese-langu age-medical-app-offers-advice-coronavirus/\#.XveU8m0zbIV Accessed 2 July 2020

The National (2020) Coronavirus: reusable face masks to ease UAE eco concerns. https://www.thenational.ae/uae/health/coron avirus-reusable-face-masks-to-ease-uae-eco-concerns- 1.10243 00. Accessed 4 July 2020

The Peninsula (2020) Robots may become heroes in war on coronavirus. https://www.thepeninsulaqatar.com/article/09/04/2020/ Robots-may-become-heroes-in-war-on-coronavirus. Accessed 30 June 2020

The Phnom Penh Post (2020) Covid-19 app contest launched. https ://www.phnompenhpost.com/national/covid-19-app-contestlaunched. Accessed 28 June 2020

The Times of India (2020) These face masks that use new technology could actually kill virus. https://timesofindia.indiatimes.com/ city/rajkot/these-face-masks-that-use-new-tech-could-actua lly-kill-virus/articleshow/75130514.cms. Accessed 3 July 2020

The World (2020) In fight against coronavirus, Ghana uses drones to speed up testing. https://www.pri.org/stories/2020-04-23/ fight-against-coronavirus-ghana-uses-drones-speed-testing. Accessed 27 June 2020

Tracetogether (2020) Tracetogether Application. https://www.trace together.gov.sg/. Accessed 2 July 2020

Twitter (2020a) It might be the largest-scale civil drone delivery in real use in the world as of today: SF express drone delivery in Hubei province, China during coronavirus. https://twitt er.com/chineseflyer/status/1239868955579293699. Accessed 2 July 2020

Twitter (2020b) AUVSI Headquarters:Alphabet's \#drone delivery company wing has seen a surge in demand in recent weeks, making over 1,000 deliveries in the last two weeks. Delivery numbers have doubled in the US and Australia. https://twitter.com/AUVSI /status/1248290844513353728. Accessed 02 July 2020

Twitter (2020c) Turkey uses a drone to deliver bread to his costumers during the coronavirus lockdown. https://twitter.com/fatihcagri i/status/1252558855608958976?s=12. Accessed 29 June 2020

UAS Magazine (2020) Italian drone dealer creates delivery box for swabs, COVID meds. http://uasmagazine.com/articles/2146/itali an-drone-dealer-creates-delivery-box-for-swabs-covid-meds. Accessed 28 June 2020

Udugama B, Kadhiresan P, Kozlowski HN et al (2020) Diagnosing COVID-19: the disease and tools for detection. ACS Nano 14:3822-3835. https://doi.org/10.1021/acsnano.0c02624

Vacca A, Onishi H (2017) Drones: military weapons, surveillance or mapping tools for environmental monitoring? The need for legal framework is required. Transp Res Proced 25:51-62. https://doi. org/10.1016/j.trpro.2017.05.209

Vhaduri S, Van Kessel T, Ko B, Wood D, Wang S, Brunschwiler T (2019) Nocturnal cough and snore detection in noisy environments using smartphone-microphones. IEEE (ICHI). https://doi. org/10.1109/ICHI.2019.8904563

We Robotics (2020) How delivery drones are being used to tackle COVID-19. https://blog.werobotics.org/2020/04/25/cargo-drone s-covid-19/. Accessed 02 July 2020

Wang S, Kang B, Ma J, Zeng X, Xiao M et al (2020) A deep learning algorithm using CT images to screen for corona virus disease (COVID-19). medrxiv. https://doi.org/10.1101/2020.02.14.20023 028

WHO (2020) Declaration of public health emergency of international concern. https://www.who.int/emergencies/diseases/novel-coron avirus-2019/events-as-they-happen. Accessed 27 June 2020

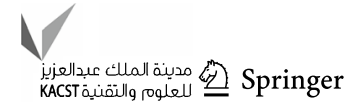


Ye Y, Hou S, Fan Y, Qian Y, Zhang Y, Sun S, Peng Q, Laparo K (2020) $\alpha$-Satellite: an AI-driven System and benchmark datasets for hierarchical community-level risk assessment to help combat COVID-19. IEEE J Biomed Inform. https://doi.org/10.1109/ JBHI.2020.3009314

Yuan M, Yin W, Tao Z, Tan W, Hu Y (2020) Association of radiologic findings with mortality of patients infected with 2019 novel coronavirus in Wuhan, China. PLoS ONE 15:e0230548-e230558. https://doi.org/10.1371/journal.pone.0230548
Zachreson C, Fair KM, Cliff OM, Harding N, Piraveenan M, Prokopenko M (2018) Urbanization affects peak timing, prevalence, and bimodality of influenza pandemics in Australia: results of a census-calibrated model. Sci Adv 4:eaau5294. https://doi. org/10.1126/sciadv.aau5294

ZD Net (2020) Google DeepMind's effort on COVID-19 coronavirus rests on the shoulders of giants. https://www.zdnet.com/article/ google-deepminds-effort-on-covid-19-coronavirus-rests-on-theshoulders-of-giants/. Accessed 3 July 2020 